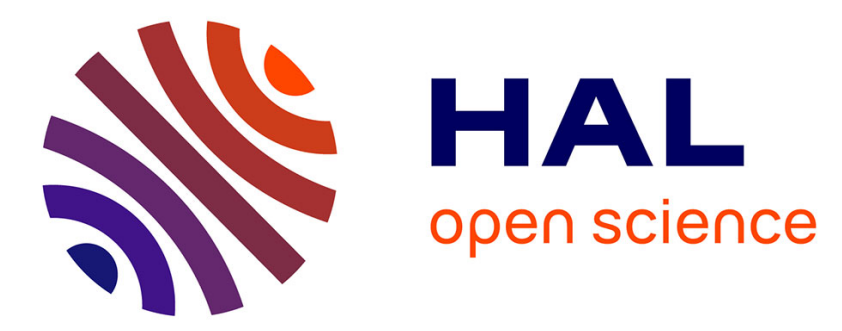

\title{
Population dynamics of Equus conversidens (Perissodactyla, Equidae) from the late Pleistocene of Hidalgo (central Mexico): comparison with extant and fossil equid populations
}

Alexis Pérez-Pérez, Victor Manuel Bravo-Cuevas, Philippe Fernandez

\section{To cite this version:}

Alexis Pérez-Pérez, Victor Manuel Bravo-Cuevas, Philippe Fernandez. Population dynamics of Equus conversidens (Perissodactyla, Equidae) from the late Pleistocene of Hidalgo (central Mexico): comparison with extant and fossil equid populations. Journal of South American Earth Sciences, 2021, 106, pp.103100. 10.1016/j.jsames.2020.103100 . halshs-03024467v2

\author{
HAL Id: halshs-03024467 \\ https://shs.hal.science/halshs-03024467v2
}

Submitted on 9 Nov 2021

HAL is a multi-disciplinary open access archive for the deposit and dissemination of scientific research documents, whether they are published or not. The documents may come from teaching and research institutions in France or abroad, or from public or private research centers.
L'archive ouverte pluridisciplinaire HAL, est destinée au dépôt et à la diffusion de documents scientifiques de niveau recherche, publiés ou non, émanant des établissements d'enseignement et de recherche français ou étrangers, des laboratoires publics ou privés. 


\section{Population dynamics of Equus conversidens (Perissodactyla, Equidae) from the late Pleistocene of Hidalgo (central Mexico): Comparison with extant and fossil equid populations}

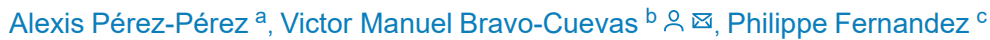

Show more $v$

:三 Outline $\mid$ o Share gy Cite

\section{Highlights}

- Paleodemography of Equus conversidens is explored by life-tables and Lewis-Leslie matrices.

- Mortality pattern of E. conversidens is a prime-dominated profile.

- Hunting pressure by non-human predators is related to the mortality pattern.

- Predation and resource availability regulate population dynamics of $E$. conversidens.

\footnotetext{
Abstract

The Mexican horse Equus conversidens is a representative member of the Quaternary North American megafauna. Systematics, phylogeny, and stable isotope ecology of this species are known in some detail, although information regarding population ecology is unexplored. Numerous fossil remains (isolated teeth, mandibles, skulls, and postcranial elements) of this horse have been collected from Pleistocene deposits that outcrop at southeastern Hidalgo, central Mexico. The available dental sample is suitable for recovering some aspects of its population dynamics. Our study compares life history traits of cohorts of E. conversidens from the state of Hidalgo to extant and Pleistocene species of equids from North America (United States and Canada), Europe (France), and Africa (Rwanda, Namibia). Life tables and age-structured models allow us to describe demographic parameters and mortality patterns. We highlight that $E$. conversidens was a typical K-strategists with high probability of surviving to adulthood with asymptotic growth rate $(\lambda=1.05)$ indicating a population close to balance. Considering the mammalian associations from different habitats in southeastern Hidalgo and the flexible diet of E. conversidens, we suggest that ambush (Panthera atrox) and cursorial predators (Canis dirus) played a major role in the prime-dominated mortality pattern of this species. The presence of a woodland-grassland ecosystem that sustained a high diversity of herbivores and the occurrence of large-sized predators suggest that the population dynamics were regulated by resource availability and selective predation, as it occurs in populations of the extant plains zebra, E. quagga.
} 


\section{Introduction}

Life tables and matrix population models are very efficient tools now widely applied in ecology to better understand the life history traits of plants and animal species (Fujiwara and Diaz-Lopez, 2017). In both cases, multiple cohorts are particularly well suited to interpret age structures through time (Fernandez et al., 2017).

Age-specific life tables were first applied in experimental biology to better understand invertebrate mortality patterns (e.g. Pearl and Miner, 1935). These models were then developed further, especially in many studies for wildlife management of large mammals (Caughley, 1966) or birds (Botkin and Miller, 1974). At the same time, matrix population models have been used to describe the evolution of multiple cohorts (projections in time, stationary versus unbalanced living populations) (Bernardelli, 1941; Lewis, 1942; Leslie 1945, 1948), followed more recently by the very well-known and impressive work of Caswell in the field of applied mathematical demography (2001).

Nevertheless, life table models have been poorly exploited in paleodemography except in a few studies involving large mammals (Kurtén, 1953; 1954a; 1954b; 1983; Van Valen, 1963; 1964; 1965; Voorhies, 1969; Reher 1970; 1973; 1974; Nimmo 1971; Hulbert, 1982; 1984; Koike and Oitaishi, 1985; 1987; Lyman, 1987; Turnbull and Martill, 1988; McDonald, 1996; Fernandez and Legendre, 2003; Mihlbachler, 2003; 2007; O'Sullivan J., 2005; Fernandez et al., 2006; Fernandez 2009; Prentiss et al., 2014), dinosaurs (Erickson et al. 2006, 2009; Steinsalz and Orzack, 2011), and small mammals (Korth and Evander, 1986; Bryant, 1991; Mihlbachler, 2012). In a similar way, age-structured Leslie models have received little interest in paleodemography although they have become a standard in population ecology (Fernandez and Boulbes, 2010; Monchot et al., 2012; Rodríguez-Gómez et al., 2014, 2016; Martín-González et al., 2016).

In this study we highlight the remarkable properties of life table demographic parameters (see below i.e. $l_{x}, s_{x}, R_{o}, r, T b$, etc.) with Leslie matrix model projections considering an outstanding sample of different horse species from different ecological contexts and mammalian associations. Our E. conversidens sample consists of at least 50 individuals from the late Pleistocene of the state of Hidalgo. Here we compare it to the fossil cohorts of Equus lambei (Bluefish Caves, Canada) (Burke and Cinq-Mars, 1998), extant Equus quagga (Akagera, Rwanda) (Spinage, 1972), Equus zebra (Khomas Hocland, Namibia) (Joubert, 1974), Equus caballus (Pryor Mountain, Montana, United States) (Garrott and Taylor, 1990), Equus hemionus (Southern and Dzungaria Gobi, Mongolia) (Lkhagvasuren et al., 2017), and Equus asinus (Grand Canyon, Arizona, United States) (Ruffner and Carothers, 1982). In addition, key paleobiological contexts in France were selected for inter-specific age structures comparisons, such as the hyena den of Fouvent with its accumulation of Equus germanicus, and the Bau de l'Aubesier with its heavy anthropogenic hunting pressure on Equus mosbachensis (Fernandez and Legendre, 2003; Fernandez et al., 2006). Each of these populations offers an exceptional opportunity to provide detailed information about recent and fossil equids whose causes of death and demographic parameters are known.

In order to avoid biases resulting from different methodological approaches, individual ages for all fossil equids were obtained from polynomial equations whose parameters were estimated by bootstrapping starting from the dental height intervals of known age individuals (Fernandez and Legendre, 2003). Ternary diagrams and histograms are used to illustrate the age frequencies between equid populations in order to relate them to the two dominant theoretical types of mortality: attritional $v s$. catastrophic, which are usually considered key components in describing fossil age structures in the zooarchaeological literature.

Taken together, all of these aspects allow us to address issues that are central to our understanding of the Pleistocene $E$. conversidens: which demographic parameters are the most sensitive to the final state of the population from southeastern Hidalgo, central Mexico? And which human or non-human predators have affected the assemblage of E. conversidens?

\section{Study area}

The studied material comes from seven neighbor localities in southeastern Hidalgo known as Ventoquipa (HGO-9: $20^{\circ}{ }^{\prime}{ }^{\prime}$

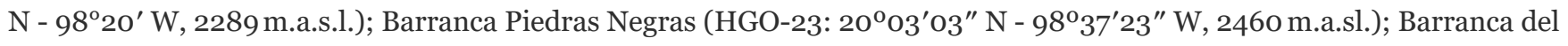
Berrendo (HGO-28: $20^{\circ} \mathrm{O1}^{\prime} 20.7^{\prime \prime} \mathrm{N}$ - 98 $38^{\circ} 37.9^{\prime \prime} \mathrm{W}, 2458$ m.a.s.l.); Barranca San Agustín (HGO-29: 20 OO'27.7" N $98^{\circ} 37^{\prime} 59.9^{\prime \prime}$ W, 2467 m.a.s.l.); Jagüey Viejo (HGO-42: $20^{\circ} 02.311^{\prime \prime} \mathrm{N}-98^{\circ} 35.885^{\prime \prime}$ W, 2528 m.a.s.l.); Arroyo las Cajas 
Download

minimum of $1.75 \mathrm{~km}$ (between HGO-28 and HGO-29) (Fig. 1). In this area, there are Quaternary deposits that consist of clay, silt, and conglomeratic lenses set in a fluvial environment (Bravo-Cuevas, 2002) (Fig. 2). An important sample of fossil remains has been recovered from these sedimentary deposits. The record includes rodents, felids, dire wolves, ground sloths, giant armadillos, horses, llamas, pronghorns, deer, bison, mammoths, gomphotheres, and mastodons (Bravo-Cuevas, 2001, 2002; Bravo-Cuevas et al., 2009a, 2009b, 2011, 2012, 2013, 2015, 2016, 2017, 2020). The presence of material belonging to Bison and Panthera atrox is related to the Rancholabrean North American Land Mammal Age (NALMA) (Bell et al., 2004). The identification of Bison antiquus indicates that the maximum age of the fossil-bearing deposits is of about 60 ka (Bravo-Cuevas and Vázquez-Cortes, 2019), corresponding to the Wisconsin glaciation in North America.

Fig. 1

Download : Download high-res image (1MB) Download : Download full-size image

Fig. 1. Index map of the study area in southeastern Hidalgo, central Mexico. The capital of the state, Pachuca city (large star) and the fossil localities are indicated. Localities: HGO-9, Ventoquipa; HGO-23, Barranca Piedras Negras; HGO-28, Barranca del Berrendo; HGO-29, Barranca San Agustín; HGO-42, Jagüey Viejo; HGO-46, Arroyo las Cajas; HGO-47, El Barrio. 
Download

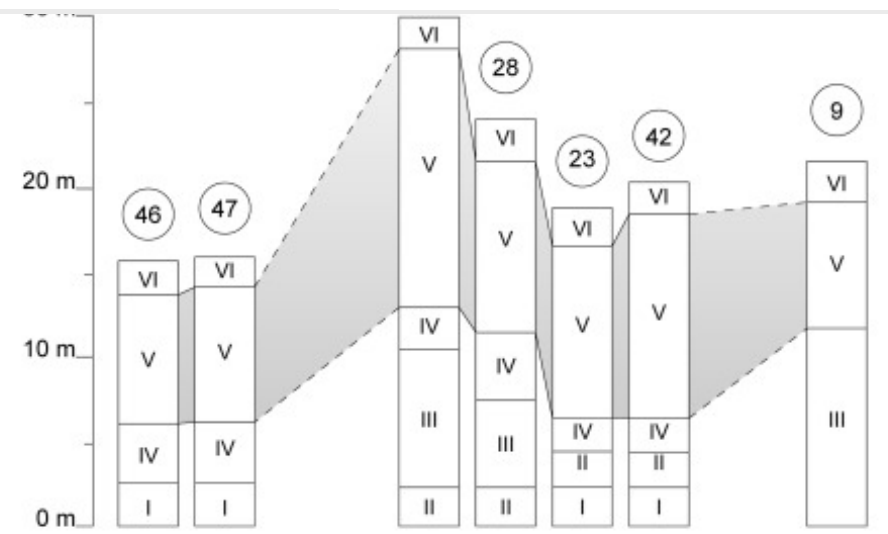

(b)

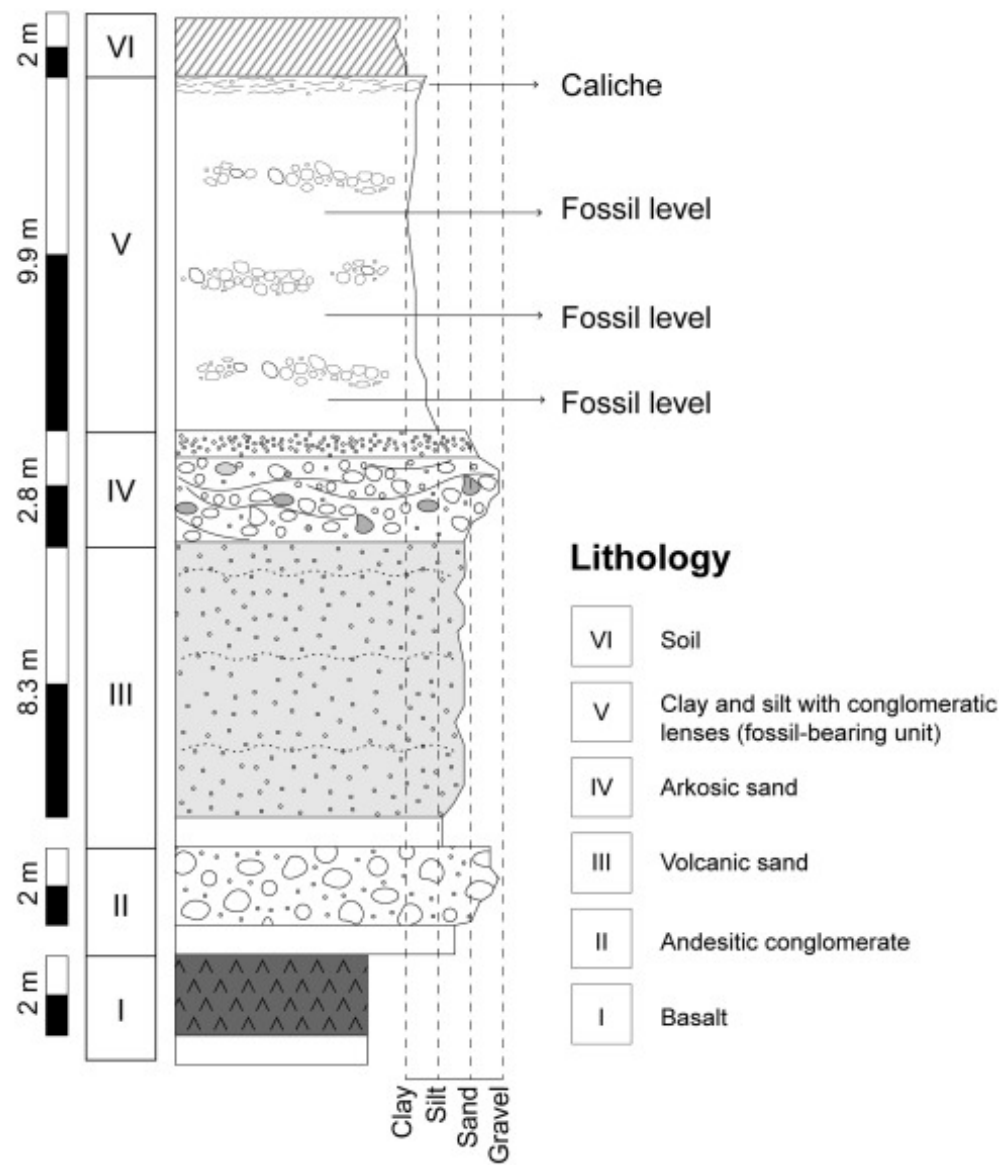

Download : Download high-res image (666KB)

Download : Download full-size image

Fig. 2. (a) Lithostratigraphic correlation of the fossil localities and (b) Generalized lithostratigraphy of the fossil localities. The localities are labeled as in Fig. 1.

\section{Material and methods}

\subsection{Dental fossil sample}

The sample referable to $E$. conversidens considered here consists of 85 dental anatomical elements (Table 1). The fossil material includes two skulls with right and left $\mathrm{P}_{2}-\mathrm{M}_{3}$, one partial skull with right $\mathrm{P}_{2}-\mathrm{M}_{3}$, one left maxillary fragment with P2-M1, one right mandible fragment with p3-m3, one right mandible fragment with p2-m2, two left mandible fragments with p2-m3, five right mandible fragments with p2-m3, one right mandible fragment with p4-m3, two mandible fragments with right and left p2-m3, and 69 isolated cheek teeth (40 of the upper dentition and 29 of the lower 
Table 1. Teeth specimens of Equus conversidens from Hidalgo. Upper/lower case for upper and lower dentition respectively ( $\mathrm{R}$, right; $\mathrm{L}$, left).

\begin{tabular}{|c|c|c|c|c|c|}
\hline Locality & Locality ID & Catalogue No. & Dental element & Crown height (mm) & Estimated age (years) \\
\hline Ventoquipa & HGO-09 & UAHMP-286 & Rp4 & 58.1 & 7.43 \\
\hline \multirow[t]{3}{*}{ Barranca Piedras Negras } & HGO-23 & UAHMP-179 & $\mathrm{RP}_{3}$ & 71.6 & 5.99 \\
\hline & & UAHMP-409 & $\mathrm{RM} 3$ & 45.8 & 9.05 \\
\hline & & UAHMP-181 & Lp4 & 53.6 & 7.94 \\
\hline \multirow[t]{27}{*}{ Barranca del Berrendo } & HGO-28 & UAHMP-941 & $\mathrm{RP} 2$ & 38.7 & 9.42 \\
\hline & & UAHMP-509 & $\mathrm{RP}_{4}$ & $57 \cdot 5$ & 8.06 \\
\hline & & UAHMP-905 & $\mathrm{RP}_{3}$ & 67.0 & 6.74 \\
\hline & & UAHMP-314 & $\mathrm{RP}_{4}$ & 63.7 & 6.83 \\
\hline & & UAHMP-319 & LM1 & $43 \cdot 3$ & 9.97 \\
\hline & & UAHMP-594 & LM1 & 13.1 & 23.85 \\
\hline & & UAHMP-901 & LM1 & $34 \cdot 7$ & 12.47 \\
\hline & & UAHMP-909 & RM1 & 34.7 & 12.47 \\
\hline & & UAHMP-316 & LM2 & 66.6 & 6.69 \\
\hline & & UAHMP-942 & LM2 & 65.0 & 6.92 \\
\hline & & UAHMP-356 & $\mathrm{LM}_{3}$ & 61.3 & $7 \cdot 36$ \\
\hline & & UAHMP-317 & $\mathrm{RM} 3$ & 20.8 & 18.67 \\
\hline & & UAHMP-939 & $\mathrm{RM} 3$ & 60.8 & 7.40 \\
\hline & & UAHMP-943 & $\mathrm{RM}_{3}$ & 67.9 & 6.75 \\
\hline & & UAHMP-215 & Lp3 & $65 \cdot 7$ & 7.00 \\
\hline & & UAHMP-353 & Lp4 & 64.7 & 6.75 \\
\hline & & UAHMP-4145 & $\mathrm{Rp} 4$ & 50.2 & 8.40 \\
\hline & & UAHMP-945 & Lm1 & 44.0 & 8.26 \\
\hline & & UAHMP-1916 & Lp4 & 66.7 & 6.51 \\
\hline & & UAHMP-403 & $\mathrm{Rm} 1$ & 28.9 & $12.5^{2}$ \\
\hline & & UAHMP-508 & $\mathrm{Rm} 1$ & 78.7 & 4.49 \\
\hline & & UAHMP-950 & $\mathrm{Rm} 1$ & 19.4 & $17 \cdot 51$ \\
\hline & & UAHMP-1915 & $\mathrm{Rm} 1$ & $54 \cdot 3$ & 6.96 \\
\hline & & UAHMP-4130 & $\mathrm{Rm} 1$ & 20.0 & 17.14 \\
\hline & & UAHMP-944 & Lm2 & 74.8 & $5 \cdot 97$ \\
\hline & & UAHMP-326 & $\mathrm{Rm} 3$ & 38.7 & 11.16 \\
\hline & & UAHMP-390 & $\mathrm{Rm} 3$ & $65 \cdot 3$ & 6.63 \\
\hline \multirow[t]{2}{*}{ Barranca San Agustín } & HGO-29 & UAHMP-417 & $\mathrm{LP}_{4}$ & 33.9 & 13.40 \\
\hline & & UAHMP-415 & LM1 & 47.4 & 9.06 \\
\hline
\end{tabular}


Download

\begin{tabular}{|c|c|c|c|c|c|}
\hline & & UАНМР-491 & LM1 & 59.6 & 7.12 \\
\hline & & UAHMP-510 & $\mathrm{RM} 3$ & 27.2 & 14.91 \\
\hline & & UAHMP-492 & Lp2 & 53.8 & $5 \cdot 33$ \\
\hline & & UAHMP-512 & Lp2 & 49.6 & 6.27 \\
\hline & & UAHMP-418 & Lp4 & $65 \cdot 3$ & 6.68 \\
\hline & & UAHMP-932 & $\operatorname{Lm} 1$ & $59 \cdot 7$ & 6.52 \\
\hline & & UAHMP-504 & Lm1 & 49.6 & 7.46 \\
\hline & & UAHMP-387 & Rm1 & 65.8 & 6.04 \\
\hline & & UAHMP-4145 & Lm2 & 56.0 & 8.36 \\
\hline & & UAHMP-495 & $\mathrm{Rm} 2$ & 41.3 & 10.62 \\
\hline & & UAHMP-416 & Lm3 & 64.8 & 6.70 \\
\hline & & UAHMP-511 & Lp3 & Unworn & 2.67 \\
\hline & & UAHMP-4170 & Rm1 & Unworn & 0.92 \\
\hline Barranca Jagüey Viejo & HGO-42 & UAHMP-935 & $\mathrm{LP} 2$ & 48.6 & 8.02 \\
\hline & & UAHMP-902 & RM1 & $37 \cdot 3$ & 11.63 \\
\hline & & UAHMP-936 & Lp4 & 28.3 & 15.47 \\
\hline & & UAHMP-949 & Rm1 & 71.2 & $5 \cdot 53$ \\
\hline & & UAHMP9O3 & $\mathrm{Rm} 2$ & 36.2 & 11.90 \\
\hline & & UAHMP-937 & $\mathrm{Rm} 2$ & 59.9 & 7.94 \\
\hline Las Cajas & HGO-46 & UAHMP-1913 & $\mathrm{LP} 2$ & $54 \cdot 9$ & 7.07 \\
\hline & & UAHMP-1911 & LM2 & 51.9 & 8.95 \\
\hline & & UAHMP-1912 & LM2 & 53.1 & 8.72 \\
\hline & & UAHMP-507 & Lp4 & 63.5 & 6.88 \\
\hline El Barrio & HGO-47 & UAHMP-2706 & $\mathrm{RP} 2$ & $37 \cdot 3$ & 9.65 \\
\hline & & UAHMP-1125 & $\mathrm{RP} 3$ & 50.1 & 9.13 \\
\hline & & UAHMP-4014 & $\mathrm{RP} 3$ & 44.8 & 10.03 \\
\hline & & UAHMP-900 & $\mathrm{LP}_{4}$ & 63.6 & 6.84 \\
\hline & & UAHMP-1116 & $\mathrm{LP}_{4}$ & 26.1 & 17.0 \\
\hline & & UAHMP-2709 & $\mathrm{LP}_{4}$ & 57.9 & 7.61 \\
\hline & & UAHMP-2711 & LP4 & 66.2 & 6.49 \\
\hline & & UAHMP-1123 & $\mathrm{RP} 4$ & 39.7 & 11.39 \\
\hline & & UAHMP-1112 & LM1 & 56.9 & 7.48 \\
\hline & & UAHMP-4017 & LM1 & 43.7 & 9.87 \\
\hline & & UAHMP-1123 & RM1 & 37.5 & 11.55 \\
\hline & & UAHMP-2712 & RM1 & 12.8 & 24.05 \\
\hline & & UAHMP-4122 & RM1 & 29.5 & 14.47 \\
\hline & & UAHMP-4123 & RM1 & 46.8 & 9.19 \\
\hline & & UAHMP-4162 & RM1 & 48.4 & 8.86 \\
\hline
\end{tabular}




$\begin{array}{llll}\text { UAHMP-A } & \text { KM1 } & 24.3 & 16.93 \\ \text { UAHMP-1910 } & \text { RM2 } & 52.9 & 8.77 \\ \text { UAHMP-4019 } & \text { RM2 } & 53.7 & 8.63 \\ \text { UAHMP-2710 } & \text { Lp3 } & 18.6 & 18.26 \\ \text { UAHMP-4018 } & \text { Lp4 } & 30.9 & 14.10 \\ \text { UAHMP-2704 } & \text { Rp4 } & 60.6 & 7.18 \\ \text { UAHMP-B } & \text { Rp4 } & 49.7 & 8.95 \\ \text { UAHMP-2704 } & \text { Lm1 } & 72.6 & 5.37 \\ \text { UAHMP-4120 } & \text { Lm1 } & 50.8 & 7.32 \\ \text { UAHMP-957 } & \text { Rm1 } & 57.3 & 6.71 \\ \text { UAHMP-1109 } & \text { Rm1 } & 34.9 & 10.37 \\ \text { UAHMP-2708 } & \text { Lm3 } & 25.3 & 15.87 \\ \text { UAHMP-4016 } & \text { Lm3 } & 71.3 & 5.48 \\ \text { UAHMP-4215 } & \text { Lm3 } & 55.5 & 8.10\end{array}$

\subsection{The fossil cohorts of E. conversidens from Hidalgo}

An ancient population or paleopopulation consists of different cohorts through time and retains the basic traits of an extant population (e.g., genetic flow, age structure, and interbreeding) (MacFadden, 2008; Fernandez et al., 2017). The time interval of a deposit should be considered to characterize a paleopopulation (Hunter, 1998). The mammalian association from Hidalgo represents a within-habitat assemblage set in a fluvial environment, time-averaging estimated limits range from decades to 100 kyrs (Behrensmeyer et al., 2000; Bravo-Cuevas et al., 2017). This time interval has been considered as a geological time duration that meets the assumption of multiple deposits corresponding to different cohort generations that interacted as an entire population (MacFadden, 2008).

MacFadden (1989) observed that intraspecific variation in dental characters in paleopopulations of fossil horses has coefficients of variation $(V)$ that range from about $4 \%$ to $10 \%$, as it occurs in extant horse populations. In this regard, the coefficients of variation related to the anteroposterior length (7.55\%) and transverse width (5.59\%) of the first upper molars of E. conversidens from the state of Hidalgo are less than 10\% (Table 2). Consequently, the fossil collection has been treated as a natural assemblage of horses of the same species that shared the same area (southeastern Hidalgo) at the same geological time-interval (late Pleistocene).

Table 2. Coefficient of variation (CV) in the anteroposterior length (APL) and transverse width (TW) of M1s of Equus conversidens from the late Pleistocene of southeastern Hidalgo, central Mexico (measurements in mm).

\begin{tabular}{lllr}
\hline Locality & ID & APL & TW \\
\hline HGO-28 & UAHMP-319 & 22.29 & 22.6 \\
HGO-28 & UAHMP-594 & 20.89 & 24.22 \\
HGO-28 & UAHMP-901 & 21.76 & 24.65 \\
HGO-28 & UAHMP-509 & 24.2 & 24.22 \\
HGO-29 & UAHMP-415 & 22.86 & 23.33 \\
HGO-29 & UAHMP-491 & 24.07 & 23.91 \\
HGO-42 & UAHMP-902 & 24.05 & 25.57
\end{tabular}




$\begin{array}{lccc} & & & 24.11 \\ \text { HGO-47 } & \text { Download } & 23.35 & 22.98 \\ \text { HGO-47 } & \text { UAHMP-1112 } & 22.18 & 25.33 \\ \text { HGO-47 } & \text { UAHMP-4017 } & 25.66 & 27.44 \\ \text { HGO-47 } & \text { UAHMP-1123 } & 20.35 & 23.55 \\ \text { HGO-47 } & \text { UAHMP-2712 } & 21.85 & 25.18 \\ \text { HGO-47 } & \text { UAHMP-4122 } & 24.92 & 26.97 \\ \text { HGO-47 } & \text { UAHMP-4123 } & 26.31 & 23.87 \\ \text { HGO-47 } & \text { UAHMP-4162 } & 21.7 & 5.59 \\ \text { CV } & \text { UAHMP-1116 } & 7.55 & \end{array}$

\subsection{Estimation of the number of individuals}

Teeth are often the best anatomical elements to estimate the number of individuals in fossil assemblages because they are better preserved than bones and represent diagnostic material for the identification of species (Lyman, 1994). The sample of $E$. conversidens from Hidalgo consists of isolated teeth, mandibles, skulls, and postcranial remains, dental elements being the most abundant (Bravo-Cuevas et al., 2011). For comparative purposes, we used two indices: Minimum Number of Individuals (MNI) (Badgley, 1986) and the total Number of Identified Specimens (NISP) (Lyman, 2008). Assuming multiples cohorts in the seven localities from central Mexico, the total MNI was summed between each one of them and calculated considering the most abundant tooth from one side of the body (left or right). Partial or complete dental series set in skulls or mandibles were counted as one individual for NISP.

When fossil deposits are produced or modified by either humans, carnivores or natural processes such as those caused by micro-organisms, we have to estimate the potential taphonomic biases. Here, we calculated the proportion between left and right teeth according the method of Brain (1981) in order to evaluate dental preservation and potential disturbances of the assemblage.

Finally, together the MNI, NISP and the dental preservation of E. conversidens were compared with middle and upper Pleistocene Equus populations from France (Table 3).

Table 3. Comparison of the minimum number of individuals (MNI) and the total number of identified specimens (NISP), the frequencies of right and left teeth, and the degree of differential preservation (following Brain, 1981) of the horse population of Equus conversidens from the late Pleistocene of southeastern Hidalgo, central Mexico, and selected populations of Pleistocene Equus from France (data from Fernandez et al., 2006: Table 3, p. 180).

\begin{tabular}{|c|c|c|c|c|c|c|}
\hline & MNI & NISP & Left teeth (LT) & Right teeth (RT) & Total expected & Differential preservation (Dp*) \\
\hline Hidalgo & 50 & 85 & 50 & 39 & 100 & $89.00 \%$ \\
\hline Bau del'Aubesier & 49 & 353 & 186 & 167 & 372 & $94.89 \%$ \\
\hline Fouvent & 54 & 464 & 353 & 326 & 706 & $96.17 \%$ \\
\hline Combe-Grenal & 67 & 396 & 173 & 218 & 436 & $89.67 \%$ \\
\hline
\end{tabular}

\subsection{Individual age and age intervals estimation}

We took into account isolated teeth and cheek teeth set in the maxilla or the mandible. We used the method of Fernandez and Legendre (2003), which uses crown height to assign each tooth (i.e., P2/p2, M3/m3 ...) to a particular age interval. 
coefficients.

The crown height (in $\mathrm{mm}$ ) was measured using a digital caliper (range $\mathrm{o}-150 \mathrm{~mm}$, resolution 0.01 $\mathrm{m}$, accuracy $0.003 \mathrm{~mm}$, and was taken from the separation of the roots, straight to the occlusal surface along the mesostyle and the ectostylid in the upper and lower cheek teeth respectively. We estimate the measurement uncertainty following the methodology of JCGM (2008), recording a set of 30 measurements of crown height on the same tooth (UAHMP-941). The measurand value is \pm 0.0005 .

The median (1), minimum and maximum (2) age (in years) for each tooth were estimated from the following equations (from Fernandez and Legendre, 2003: Table 5, pp. 1583; Fernandez et al., 2006: Table 2, pp. 180):

$$
\begin{aligned}
& A g e=a_{0}+a_{1} H+a_{2} H^{2}+a_{3} H^{3} \\
& A g e=\left(a_{0}+a_{1} H+a_{2} H^{2}+a_{3} H^{3}\right) \pm 2 E
\end{aligned}
$$

In these equations, $\mathrm{a}_{\mathrm{o}}=$ slope; $\mathrm{a}_{1}, \mathrm{a}_{2}, \mathrm{a}_{3}=$ intercept; $H=$ crown height, and $E=$ mean prediction error. Estimation of the age distribution of each tooth in appropriate age intervals is detailed in the step-by-step procedure of Fernandez (2009: Fig. 1, pp. 7). In this study, we also compared the age distributions derived from the MNI on the one hand, and the NISP on the other hand using a Kolmogorov-Smirnov non-parametric test and Spearman's rank-order correlation coefficient (Klein and Cruz-Uribe, 1984; Vasileiadou et al., 2007) (Table 4).

Table 4. Comparison of age distribution derived from the minimum number of individuals (MNI) and the total number of identified specimens (NISP) indices, using a Kolmogorov-Smirnov test $(\mathrm{K}-\mathrm{S}=0.735, \mathrm{p}>0.10)$ and Spearman's rank correlation coefficient $\left(r_{s}=0.881, \mathrm{p}>0.01\right)$.

\begin{tabular}{lll}
\hline Age interval & MNI & NISP \\
\hline $0-3$ & 1.70 & 1.75 \\
$3-6$ & 7.82 & 37.39 \\
$6-9$ & 26.37 & 17.68 \\
$9-12$ & 6.23 & 7.07 \\
$12-15$ & 3.12 & 6.23 \\
$15-18$ & 3.02 & 2.14 \\
$18-21$ & 0.73 & 2.00 \\
$21-24$ & 1.00 & 85 \\
Number of individuals & 50 & \\
\hline
\end{tabular}

Table 5. Life tables of E. conversidens (age intervals of three years) using the minimum number of individuals (MNI) and the number of identified specimens (NISP) indices. Demographic parameters described as it is indicated in the method.

\begin{tabular}{cccccc} 
& $\mathbf{x}$ & $\mathbf{n}_{\mathbf{x}}$ & $\mathbf{d}_{\mathbf{x}}$ & $\mathbf{l}_{\mathbf{x}}$ & $\mathbf{s}_{\mathbf{x}}$ \\
\hline MNI & 0 & 0.00 & 0.000 & 100.000 & 0.966 \\
& 3 & 1.70 & 3.399 & 96.601 & 0.838 \\
& 6 & 7.82 & 15.643 & 80.958 & 0.348 \\
& & 26.37 & 52.749 & 28.210 & 0.558
\end{tabular}






\subsection{Mortality patterns}

We established the age structure of the population of $E$. conversidens with both histograms and ternary diagrams, as they are the most common tools to compare mortality profiles (Stiner, 1991, 1994; Steele, 2005; Steele and Weaver, 2002; Discamps and Costamagno, 2015). MNI and NISP indices were used in histograms where each bar represents the number of individuals that died in each age interval (Fig. 3a). To show the mortality patterns of equids proposed by Discamps and Costamagno, we rebuilt the limits of the areas of the ternary diagram. In the present study, three age categories were retained as with the extant plains zebra E. quagga from the Serengeti (Grange et al., 2004: p. 526):

1) Juveniles $(\mathrm{J})=$ non-reproductive individuals with an age of $\mathrm{o}-3$ years (year 3 ending at 36 months).

2) Prime adults $(\mathrm{Pa})=$ individuals with an age of 3-15 years (year 3 beginning at 37 months), including potentially reproductive individuals like young adults and adults.

3) Old adults $(\mathrm{Oa})=$ individuals with an age greater than 15 years.

(a)

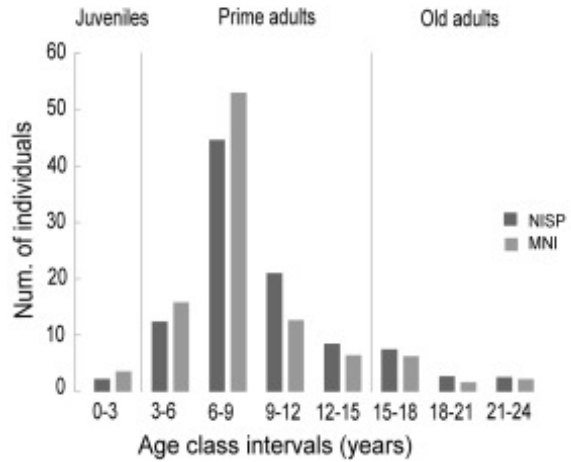

Download : Download high-res image (217KB) (b)

Old

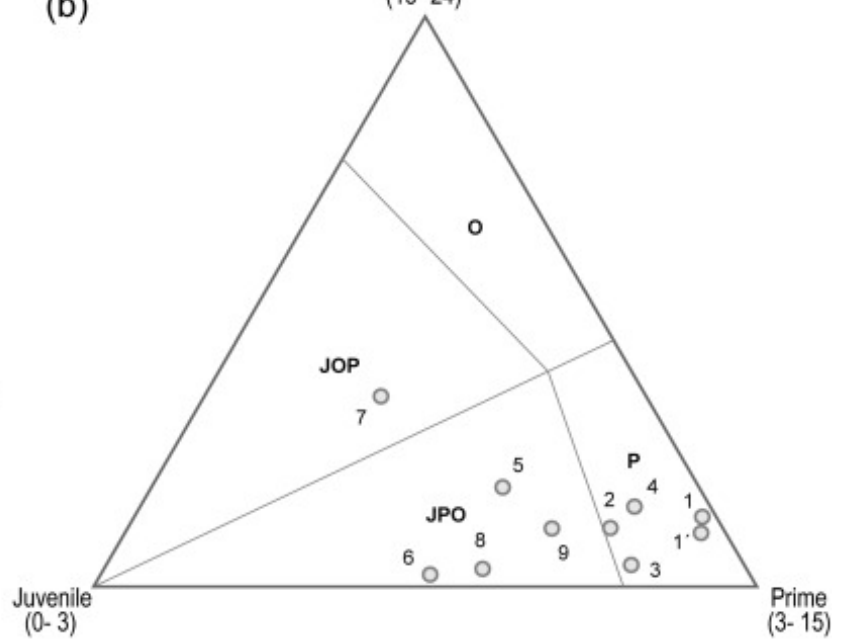

Download : Download full-size image 


\section{Download}

extinct and extant Equus. Horse populations: 1, E. conversidens (NISP); 1', E. conversidens (MNI); 2, E. lambei; 3, E. mosbachensis; 4, E. germanicus; 5, E. quagga; 6, E. zebra; 7, E. caballus; 8, E. asinus; 9, E. hemionus.

The fraction of Potential Ecological Longevity (PEL) of the population of Equus conversidens from Hidalgo was estimated assuming a PEL of about 24 years, corresponding to the oldest individuals (UAHMP-594: $23.85 \pm 0.38$ years and UAHMP-2712: $24.05 \pm 0.389$ ), which is comparable to that of the extant E. quagga (Spinage, 1972). The PEL was used for the graphical demarcation between the zones in the ternary diagram, considering the following areas: Juveniles-PrimeOld (JPO), Juveniles-Old-Prime (JOP), Prime (P), and Old (O) (sensu nomenclature of Discamp and Costamagno, 2015). The fraction of PEL to each age category is as follows: Juveniles $=12.5 \%$, Prime adults $=50 \%$, and Old adults $=37.5 \%$ (Discamp and Costamagno, 2015).

Finally, the mortality pattern of E. conversidens from Hidalgo was compared with selected Pleistocene and extant populations of Equus.

\subsection{Population dynamics: life tables and Leslie matrices}

A static or time-specific life table model was constructed based on vertical or cross-sectional analysis (i.e., Caughley, 1977; Dodd and Stanton, 1990). This model is suitable for the analysis of the E. conversidens population because it considers individuals of all ages belonging to different cohorts and multiple diachronic deposits over time (Fernandez et al., 2017). In this regard, two assumptions must be taken into account:

(1) time-specific life tables are female-dominated models. However, it is widely accepted that male survival does not affect the population growth rate of most natural mammalian populations (Caswell and Weeks, 1986; Lindström and Kokko, 1998). This implies a balanced sex-ratio at birth (1:1) and a fecundity rate that is half the number of offspring produced alive at birth by a female of a given age.

(2) it is assumed that the migration processes did not influence the age structure of the studied population (Caughley, 1977).

The life table parameters used here are defined below (see also Fernandez et al., 2017).

- $\left(_{x}\right.$ ) refers indiscriminately either to "age interval" or "age class". Nevertheless, strictly speaking the former begins at o and the latter at 1 (Caswell, 2001). In this study the standardization of one-year age intervals was derived from the $s_{x}$ values following the procedure of Fernandez and Boulbes (2010: p. 801).

- $\left(n_{x}\right)$ is the number of individuals in each age interval. It is derived either starting from the MNI or from the NISP (see calculation above).

- $\left(d_{x}\right)$ refers to the proportion of individuals of the whole cohort(s) dying in each age interval. It can be estimated as follows:

$d_{x}=\left(n_{x} / \sum n_{x}\right) * 100$ orby $d_{x}=\left(l_{x} / l_{x+1}\right)$

- $\left(l_{x}\right)$ is the cumulated survivorship and corresponds to the fraction of a cohort that survives to an age $x$. The first value can be expressed per 1, 100, or 1000 and subsequent values are estimated as:

$l_{x+1}=\left(l_{x}-d_{x}\right)$

In a standardized life table with regular pooled age-class intervals where $d_{x}$ is not available, the algebraic relation with $s_{x}$ calculates the proportion:

$l_{x+1}=\left(s_{x} * l_{x}\right)$

- $\left(s_{x}\right)$ refers to the age-specific survival rate. The rate of individuals that survived from age $x$ to $x+1$ :

$s_{x}=\frac{l_{x+1}}{l_{x}}$

- $\left(m_{x}\right)$ refers to the fecundity rate. This variable is defined as the average number of descendants per age interval. 
half the number of offspring alive at birth produced by a female in each age class, assuming a balanced sexual ratio between males and females of 1:1.

The fecundity of $E$. conversidens from Hidalgo is derived from the age-dependent birth and survival patterns observed in females of the extant plains zebra E. quagga (Rubenstein and Nuñez, 2009: table 8.2, p. 206), considering their close phylogenetic relationships (Barrón-Ortiz et al., 2019). To obtain a more accurate approximation in the fecundity rate, we assumed that as in E. quagga, females with an age from 17 to 21 years decreased their fecundity by $6.49 \%$ (Grange et al., 2004), whereas females over 21 years show low survivorship expectancy by having commonly a null fecundity (Spinage, 1972; Smuts, 1976).

- $\left(l_{x} m_{x}\right)$ refers to the contribution of a given age interval to the population reproduction as the product of $l_{x}$ and $m_{x}$.

- $\left(R_{o}\right)$ refers to the net reproductive rate of a fossil cohort that is calculated as follows:

$R_{0}=\sum l_{x} m_{x}$

In this regard, if $R_{O}<1$ indicates that population is declining whereas if $R_{o}>1$ indicates an increasing population and $R_{o}=1$ means a perfect stationary population (Monchot et al., 2012; Martín-González et al., 2016).

Since the pioneer articles of Leslie $(1945,1948)$, the so-called Leslie matrices have become a standard in population ecology with the impressive book of Caswell (2001). A projection matrix reveals whether the age structure of the different cohorts is related to a stationary population at any particular time. It gives both the picture of the initial fossil sample and the projection in time of the entire population to characterize its viability of a population. Here we used the simplest matrix projection model known as Lewis-Leslie:

$\left[\begin{array}{lllll}m_{0} & m_{1} & m_{2} & \ldots & m_{24} \\ S_{0} & 0 & 0 & \ldots & 0 \\ 0 & S_{1} & 0 & \ldots & 0 \\ \vdots & \vdots & \vdots & \ddots & 0 \\ 0 & 0 & 0 & S_{23} & 0 \\ A & & & & \end{array}\right] *\left[\begin{array}{ll}n_{0}(t) \\ n_{1}(t) \\ n_{2}(t) \\ \vdots \\ n_{24}(t) \\ n & (t)\end{array}\right]=\left[\begin{array}{ll}n_{0}(t+1) \\ n_{1}(t+1) \\ n_{2}(t+1) \\ \vdots \\ n_{24}(t+1) \\ n & (t+1)\end{array}\right]$

Matrix $A$ contains the age-specific fecundity rates $\left(m_{0}, m_{1} \ldots\right)$ as in the life tables. The diagonal contains the age-specific survival rates $\left(s_{0}, s_{1} \ldots\right)$ that corresponds to the values of $s_{\mathrm{x}}$. The vector $n(t)$ is obtained from the $l_{x}$, as the fraction of the total number of individuals in one-year intervals, whereas the vector $n(t+1)$ is the new number of individuals in each age interval at the next succeeding census of the projected population $[A n(t)=n(t+1)]$ (see details in Fernandez et al., 2017). The population projection of E. conversidens was performed using the software PopTools version 3.o.6 (Hood, 2008).

We first entered the age-specific survival $\left(s_{x}\right)$ and the fecundity data $\left(m_{x}\right)$ of the horse's population into our pre-breeding matrix as it is the basic model used for mammals (see Caswell, 2001). The projection returns the asymptotic growth rate $(\lambda)$, the exponential growth rate $(r)$, and the mean generation time $\left(T_{b}\right)$ that corresponds to the mean age of a female giving birth in a reproductive event (Leslie, 1966). In this regard, decreasing populations are characterized by having $\lambda$ less than 1 and negative values for $r$. On the contrary, increasing populations have values greater than 1 for $\lambda$ and positive values for $r$. In ideal conditions stationary populations have $\lambda=1$ and $r=0$ values (Lemos-Espinal et al., 2005; Fernandez et al., 2017).

Mammalian populations often show early fluctuations in the asymptotic growth rate, which is known as transient dynamics. In this regard, the damping ratio $\left(\rho=\frac{\lambda_{1}}{\left|\lambda_{2}\right|}\right)$ describes how fast the transient dynamics is stabilized after perturbation around the asymptotic growth rate regardless of population structure (Fernandez et al., 2017). We calculated the damping ratio using the software R Studio vr. 1.1.463, package popdemo (RStudio Team, 2015; Stott, 2018).

We also performed a disturbance analysis using the PopTool software (Hood, 2008), to explore the elasticity of the asymptotic growth rate related to changes in survival and fertility rates (see details in Caswell, 1978). The elasticity of the E. conversidens population from Hidalgo was compared and plotted with that of selected Pleistocene and extant Equus populations using ternary diagrams (Oli, 2004). We considered here: (1) elasticity of the survival of juveniles [e (Sj)], which is the sum of the elasticity values of individuals from o to 3 years; (2) elasticity of adult survival [e ( $\mathrm{Sa}$ )], which is 
The population dynamics and elasticities of E. conversidens were compared to the following equid populations: $E$. lambei from the Bluefish Caves, Wisconsinian of Yukon, Canada; in France E. germanicus from Fouvent, Oxygene Isotopic Stage 3; E. mosbachensis from Bau de l'Aubesier, Oxygene Isotopic Stage 7-6; and the extant populations of the plains zebra E. quagga from Akagera, Rwanda; and the mountain zebra E. zebra from Khomas Hochland, Namibia (Spinage, 1972; Joubert, 1974; Burke and Cinq-Mars, 1998; Fernandez and Legendre, 2003; Fernandez et al., 2006; Fourvel et al., 2014, 2015) (Supplementary Data).

\section{Results and discussion}

\subsection{Population size}

The estimated number of individuals in the sample of $E$. conversidens is 50 and 85 from MNI and NISP indices respectively. Classical works on population dynamics of ancient populations have shown that sample sizes between 30 and 40 individuals are suitable for interpreting important demographic features (see Kurtén, 1953; 1954a; 1954b). Lyman (1987) also demonstrated that about 30 individuals are necessary if 10 age classes are used but this critical assumption is often overlooked in zooarchaeological literature. In fact, optimal MNI depends on both the standard deviation of individual age and mean prediction error for each tooth category that will condition the width of the interval age classes, as well as their number (see details in Fernandez et al., 2017, Fig. 1, p. 480). The dental preservation of E. conversidens calculated from Brain (1981) is comparable to that of Combe-Grenal and is somewhat lower in comparison to the Pleistocene French sites of the Bau de l'Aubesier and Fouvent (Table 3). This suggests limited taphonomical biases for dental material between different deposits of our sample.

The Kolmogorov-Smirnov test indicates non-significant differences between MNI or NISP indices in the age distribution of $E$. conversidens $(\mathrm{K}-\mathrm{S}=0.74 ; \mathrm{p}>0.10)$ and the Spearman's rank correlation coefficient indicates a positive correlation between the estimated age distributions ( $r s=0.881, \mathrm{p}>0.01$ ) (Table 4, Fig. 3a). It is not surprising that NISP and MNI both suggest the same age distribution, because it has been demonstrated that they were not independent of one another (see detailed discussions in Grayson, 1979, 1984; Lyman, 2008).

\subsection{Mortality profiles}

The mortality profiles of $E$. conversidens show a right asymmetry and a leptokurtic distribution. These profiles do not fit the basic attritional (U-shaped) and catastrophic (L-shaped) mortality patterns. The observed patterns are more similar to the stalking-model proposed by Levine (1983: Fig. 4.8, p. 31) (Fig. 3a). Hunting mainly of prime adults with a bellshaped distribution produces this pattern (Levine, 1983). Even if the dental preservation of our sample is quite good, this kind of distribution has also often been documented in North American bison kill sites. Herds of animals were killed and their mortality pattern is usually attributed to poor preservation of the less ossified bones and teeth of youngsters (e.g., Munson, 2000; Munson and Garniewicz, 2003; Munson and Marean, 2003).

The prime adults of the age interval 6-9 years represent 52.75\% (MNI) and 44.41\% (NISP), whereas the juveniles and old adults of the age intervals $0-3$ years and 21-24 years respectively represent each less than 10\% of individuals for both indices (Fig. 3a). The high percentage of prime adult individuals in comparison to individuals of other age classes may be the result of an accumulation over time where predation played an important role (Levine, 1983). Other horse populations showing this pattern have been related to the influence of human and/or non-human predators, including the population of E. lambei from Bluefish Caves, late Pleistocene of Canada (humans and large-sized predators, such as wolf, bear, and lion) (Burke and Cinq-Mars, 1998); the population of E. mosbachensis (Level I) from Bau de l'Aubesier, Upper Pleistocene of southern France (selective hunting by Neanderthals) (Fernandez and Legendre, 2003); and the paleopopulation of E. germanicus from Fouvent, Upper Pleistocene of eastern France (hyena den) (Fernandez et al., 2006).

The predominance of young adults and mature adults indicates a prime-dominated mortality pattern (Stiner, 1990; Kahlke and Gaudzinski, 2005; Bai et al., 2011). This pattern is consistent with the location of the population of E. conversidens in the ternary diagram, within the Prime adult area (P) (Fig. 3b). The comparison with selected populations of fossil and extant Equus shows that E. lambei, E. mosbachensis, and E. germanicus also fall within the Prime adult area (P) whereas E. quagga, E. zebra, E. asinus, and E. hemionus are located within the Juveniles-Prime-Old area (JPO). Only 
A prime-dominated mortality pattern has been interpreted to reflect selective hunting strategies by humans (Stiner, 1990, 1991, 1994; Driver and Maxwell, 2013); however, there is an ecologically complementary influence by non-human predators (Marín et al., 2017). This mortality pattern has been observed in large ungulates, including several Pleistocene horse populations (e.g., Levine, 1983; Fernandez and Legendre, 2006; Marín et al., 2017).

The studied sample does not show anthropic traces, and direct (e.g., bone remains) or indirect evidence (e.g., stone tools or bone surface modifications) of humans in southeastern Hidalgo during the late Pleistocene is not reported. However, the mammalian fauna from the late Pleistocene of southeastern Hidalgo includes large-sized predators, such as dire wolf Canis dirus and American lion Panthera atrox (Bravo-Cuevas et al., 2009, 2016). Equus conversidens represented a suitable prey for these predators (Bravo-Cuevas et al., 2016). Given this, the mortality profile of $E$. conversidens from Hidalgo probably was the result of the influence of these predators, providing high return rates to these carnivores (Stephens and Krebs, 1986).

\subsection{Life tables and Leslie matrices}

Table 5, Table 6 indicate the vital statics of the population of Equus conversidens from Hidalgo.

Table 6. Standardized life tables of E. conversidens (age intervals of one year) using the minimum number of individuals (MNI) and the number of identified specimens (NISP) indices. Demographic parameters described as it is indicated in the method.

\begin{tabular}{|c|c|c|c|c|c|}
\hline & $\mathbf{x}$ & $\mathbf{l}_{\mathrm{x}}$ & $\mathbf{S}_{\mathbf{x}}$ & $\mathbf{m}_{\mathbf{x}}$ & $\mathbf{l}_{\mathbf{x}} \mathbf{m}_{\mathrm{x}}$ \\
\hline \multirow[t]{21}{*}{ MNI } & o & 1.000 & 0.989 & 0.000 & 0.000 \\
\hline & 1 & 0.989 & 0.989 & 0.000 & 0.000 \\
\hline & 2 & 0.977 & 0.989 & 0.000 & 0.000 \\
\hline & 3 & 0.966 & 0.943 & 0.105 & 0.101 \\
\hline & 4 & 0.911 & 0.943 & 0.105 & 0.096 \\
\hline & 5 & 0.859 & 0.943 & 0.105 & 0.090 \\
\hline & 6 & 0.810 & 0.704 & 0.340 & 0.275 \\
\hline & 7 & 0.570 & 0.704 & 0.340 & 0.194 \\
\hline & 8 & 0.401 & 0.704 & 0.340 & 0.136 \\
\hline & 9 & 0.282 & 0.823 & 0.340 & 0.096 \\
\hline & 10 & 0.232 & 0.823 & 0.340 & 0.079 \\
\hline & 11 & 0.191 & 0.823 & 0.460 & 0.088 \\
\hline & 12 & 0.157 & 0.845 & 0.460 & 0.072 \\
\hline & 13 & 0.133 & 0.845 & 0.460 & 0.061 \\
\hline & 14 & 0.112 & 0.845 & 0.460 & 0.052 \\
\hline & 15 & 0.095 & 0.714 & 0.460 & 0.044 \\
\hline & 16 & 0.068 & 0.714 & 0.460 & 0.031 \\
\hline & 17 & 0.048 & 0.714 & 0.430 & 0.021 \\
\hline & 18 & 0.035 & 0.833 & 0.430 & 0.015 \\
\hline & 19 & 0.029 & 0.833 & 0.430 & 0.012 \\
\hline & 20 & 0.024 & 0.833 & 0.430 & 0.010 \\
\hline
\end{tabular}


Download

$\begin{array}{rrrrr}21 & 0.020 & 0.833 & 0.430 & 0.009 \\ 22 & 0.017 & 0.833 & 0.000 & 0.000 \\ 23 & 0.014 & 0.833 & 0.000 & 0.000 \\ 24 & 0.012 & 0.833 & 0.000 & 0.000 \\ & & & R_{o}= & 1.48\end{array}$

NISP

\begin{tabular}{|c|c|c|c|c|}
\hline o & 1.000 & 0.993 & 0.000 & 0.000 \\
\hline 1 & 0.993 & 0.993 & 0.000 & 0.000 \\
\hline 2 & 0.986 & 0.993 & 0.000 & 0.000 \\
\hline 3 & 0.979 & 0.957 & 0.105 & 0.103 \\
\hline 4 & 0.937 & 0.957 & 0.105 & 0.098 \\
\hline 5 & 0.896 & 0.957 & 0.105 & 0.094 \\
\hline 6 & 0.857 & 0.784 & 0.340 & 0.291 \\
\hline 7 & 0.672 & 0.784 & 0.340 & 0.228 \\
\hline 8 & 0.527 & 0.784 & 0.340 & 0.179 \\
\hline 9 & 0.413 & 0.792 & 0.340 & 0.140 \\
\hline 10 & 0.327 & 0.792 & 0.340 & 0.111 \\
\hline 11 & 0.259 & 0.792 & 0.460 & 0.119 \\
\hline 12 & 0.205 & 0.841 & 0.460 & 0.094 \\
\hline 13 & 0.173 & 0.841 & 0.460 & 0.079 \\
\hline 14 & 0.145 & 0.841 & 0.460 & 0.067 \\
\hline 15 & 0.122 & 0.736 & 0.460 & 0.056 \\
\hline 16 & 0.090 & 0.736 & 0.460 & 0.041 \\
\hline 17 & 0.066 & 0.736 & 0.430 & 0.028 \\
\hline 18 & 0.049 & 0.785 & 0.430 & 0.021 \\
\hline 19 & 0.038 & 0.785 & 0.430 & 0.016 \\
\hline 20 & 0.030 & 0.785 & 0.430 & 0.013 \\
\hline 21 & 0.024 & 0.785 & 0.430 & 0.010 \\
\hline 22 & 0.018 & 0.785 & 0.000 & 0.000 \\
\hline 23 & 0.014 & 0.785 & 0.000 & 0.000 \\
\hline 24 & 0.011 & 0.785 & 0.000 & 0.000 \\
\hline & & & $R_{o}=$ & 1.79 \\
\hline
\end{tabular}

The net reproductive rate ( $R o$ ) was 1.48 and 1.79 using MNI and NISP indices respectively (Table 6), suggesting an increasing population. The observed Ro in all selected populations of Equus varies from 1.44 to 1.87, except for E. zebra that showed a value of 0.40 (Table 7). Ro >1 indicates an increasing population (Monchot et al., 2012; Martín-González et al., 2016).

Table 7. Comparison of the net reproductive rate (Ro), mean generational time $\left(T_{b}\right)$, exponential growth rate ( $r$ ), growth rate $(\lambda)$, and damping ratio $(\rho)$ of the population of Equus conversidens from Hidalgo and selected populations of extinct 


\begin{tabular}{|c|c|c|c|c|c|}
\hline Population & Ro & $T_{b}$ & $\boldsymbol{r}$ & $\lambda$ & $\rho$ \\
\hline A & $1.48,1.79$ & $9.21,9.41$ & $0.04,0.06$ & $1.04,1.06$ & $1.21,1.24$ \\
\hline B & 1.66 & 9.08 & 0.07 & 1.07 & 1.21 \\
\hline $\mathrm{C}$ & 1.44 & 6.86 & 0.05 & 1.05 & 1.36 \\
\hline $\mathrm{D}$ & 1.87 & 7.53 & 0.08 & 1.08 & 1.29 \\
\hline $\mathrm{E}$ & 1.78 & 10.31 & 0.06 & 1.05 & 1.21 \\
\hline $\mathrm{F}$ & 0.40 & 8.40 & -0.11 & 0.89 & 1.37 \\
\hline
\end{tabular}

The mean generation time ( $\mathrm{Tb}$ ) of the population of E. conversidens is 9.21 and 9.41 using the MNI and NISP indices respectively, indicating that females produced an average of 1.63 descendants in about 9.31 years. This pattern of an increasing population is also observed in E. lambei, E. mosbachensis, E. quagga, and E. germanicus, although the latter population should be related to rapid population growth because females produced 1.87 descendants in about 7.53 years. By contrast, the population of E. zebra is related to a declining population, considering that females produced 0.40 descendants in about 8.4 years (Table 7).

The exponential growth rate (r) related to the population growth of E. conversidens is 0.04 (MNI) and 0.06 (NISP) which is very close to other selected species where $r$ is about 0.06 ; only E. zebra has an $r=-0.11$ indicating that the number of individuals in the population decreased by $11 \%$ each year (Table 7).

The asymptotic growth rate $(\lambda)$ of E. conversidens and the other selected horse populations is $>1$, except for E. zebra where $\lambda$ is $<1$ (Table 7). The average asymptotic growth rate for the species considered (excluding E. zebra) is 1.06. In this regard, when $\lambda=1$ suggests perfect stability and a non-impacted population (Fernandez et al., 2017). Ransom et al. (2016: pp.76) reported average $\lambda$ of 1.12 for populations of wild and feral equids, Gaillard et al. (2000: pp. 370) indicated values of $\lambda$ ranging from 1.25 to 1.35 related to maximum annual population growth rates in extant equids, and Fernandez et al. (2017: pp. 488) reported values ranging from 1.21 to 1.26 in extant populations of wild equids that all evolve in optimal conditions. The values of $\lambda$ for the population of E. conversidens (MNI: 1.04, NISP: 1.06) from Hidalgo are somewhat lower than those observed in some populations of extant wild horses, although similar to the populations of $\mathrm{E}$. lambei $(\lambda=1.07)$, E. mosbachensis $(\lambda=1.05)$, and E. germanicus $(\lambda=1.08)$ (Table 7$)$.

Some populations of E. caballus and Equus ferus przewalskii inhabited areas without significant pressure from predators, presenting somewhat high survival rates in all age class intervals (Ransom et al., 2016). By contrast, the populations of E. lambei, E. mosbachensis, and E. germanicus are related to the selective influence of diverse predators with a preference for adult individuals (Burke and Cinq-Mars, 1998; Fernandez and Legendre, 2003; Fernandez et al., 2006). This could have occurred in the population of Equus conversidens from Hidalgo, which is in agreement with the observed prime-dominated mortality pattern.

The analysis of population dynamics of $E$. conversidens from Hidalgo suggests a relatively stable increasing population with slow growth $(\lambda=1.05, \mathrm{~Tb}=9.31)$. Similar population dynamics are observed in stable populations of the modern plains zebra E. quagga from Serengeti, Tanzania $(\lambda=1.01, \mathrm{~Tb}=8.24)$ (Grange et al., 2004), and different to that of declining populations of the same species from Hwange, Zimbabwe related to intensive predation $(\lambda=0.094, \mathrm{~Tb}=12.58)$ (Grange et al., 2015).

The damping ratio ( $\rho$ ) of the population of E. conversidens is about 1.22 (Table 7). A damping ratio greater than 1 indicates a population that stabilized around the $\lambda$ somewhat rapidly after perturbations regardless of population structure (Fernandez et al., 2017). Here this parameter is slightly greater than 1 for all the species considered, suggesting the convergence to stable size distribution was not so rapid. According to their values of $\rho$, a similar pattern should be expected for the populations of E. conversidens, E. lambei, and E. quagga and to a lesser extent with E. germanicus (Table 7). 
both indicate an increasing population; a similar pattern is observed in the populations of $E$. mosbachensis and $E$. quagga. Furthermore, E. germanicus has the fastest population growth, which is consistent with its highest values of net reproductive rate, exponential growth rate, and growth rate among the populations compared (Fig. 4, Table 7). By contrast, E. zebra is the only species that shows a negative growth curve reflecting a declining population (Fig. 4).

(a)

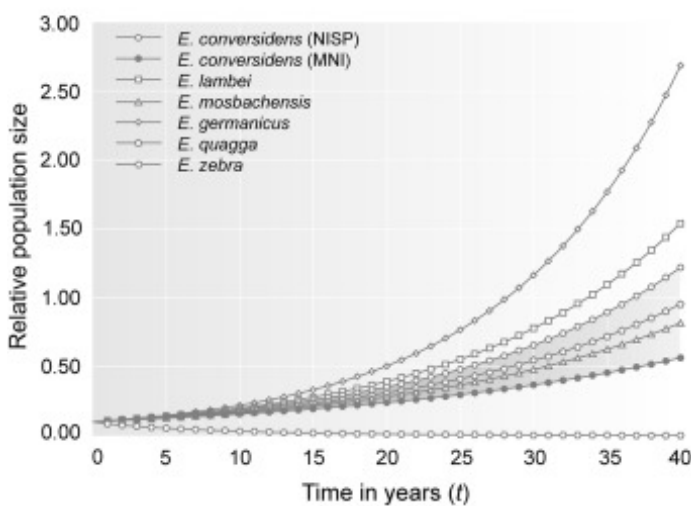

Download : Download high-res image (288KB) (b)

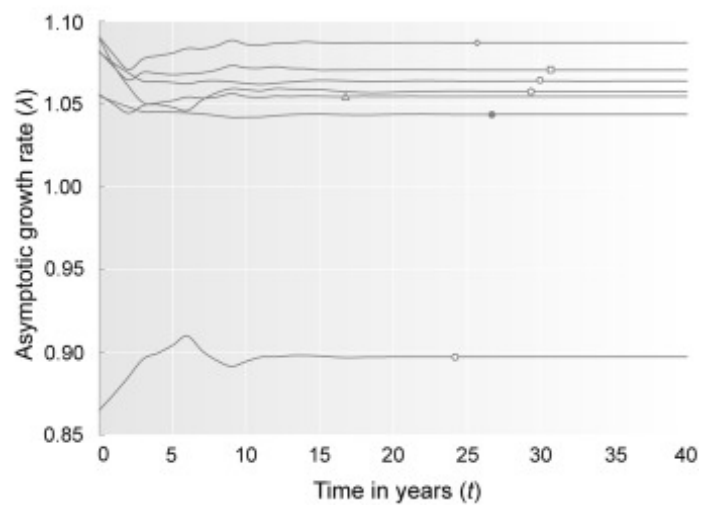

Download : Download full-size image

Fig. 4. (a) Projection of the population growth and (b) transient dynamics of Equus conversidens from the late Pleistocene of Hidalgo and selected populations of extinct and extant Equus.

The fluctuations of the asymptotic growth rate $(\lambda)$ suggest that the population of $E$. conversidens stabilized at the projection time $t_{27}$ and $t_{31}$ derived from the MNI and NISP indices respectively. The projection from the MNI shows that the lambda values decreased from the time $t_{o}(\lambda=1.055)$ to t9 $(\lambda=1.042)$, indicating fluctuations in the age structure during this time interval and the slower population growth; other minor fluctuations should occur before reaching stabilization at $t_{27}$. The projection from the NISP shows that the lambda values decreased from the time $t_{o}(\lambda=1.081)$ to t6 $(\lambda=1.062)$, indicating major fluctuations during this time interval and reaching stabilization at $t_{31}$ where the population experienced faster and constant growth (Fig. 4b). Both projections suggest fluctuations in the age structure related to juvenile ( $0-3$ years) and young-adults (3-6 years) age classes, occurring when the population experienced slower growth. Usually, these early fluctuations in the projection of a population are related to the initial conditions of the demographic parameters in the age structure (Fernandez et al., 2017).

The projection curve of E. conversidens is very similar to that of E. germanicus $\left(t_{26}\right)$, E. quagga $\left(t_{29}\right)$, and $E$. lambei $\left(t_{31}\right)$, whereas the population of $E$. mosbachensis converge to stable size more rapidly ( $\left.t_{17}\right)$ (Fig. $\left.4 \mathrm{a}\right)$. All of these fluctuations are consistent with the observed damping ratios for each species.

The elasticity values derived from all species are shown in the ternary diagram of Fig. 5. It indicates that survival, compared to fertility, is the most important demographic parameter in the population growth. It has been observed that survival is an important demographic pattern in the population growth of ungulates (Gaillard et al., 2000; Oli, 2004; Funston and Mills, 2006). In the ternary diagram, the population of E. conversidens and the selected horse populations occupy a plot space with average elasticity values of fecundity lesser than $0.20(e(F)=0.12)$ and average elasticity values of survival greater than $0.80(e(S \mathrm{j})=0.46 ; e(\mathrm{Sa})=0.42)$. These values are related to populations with slow life histories (Oli, 2004). 


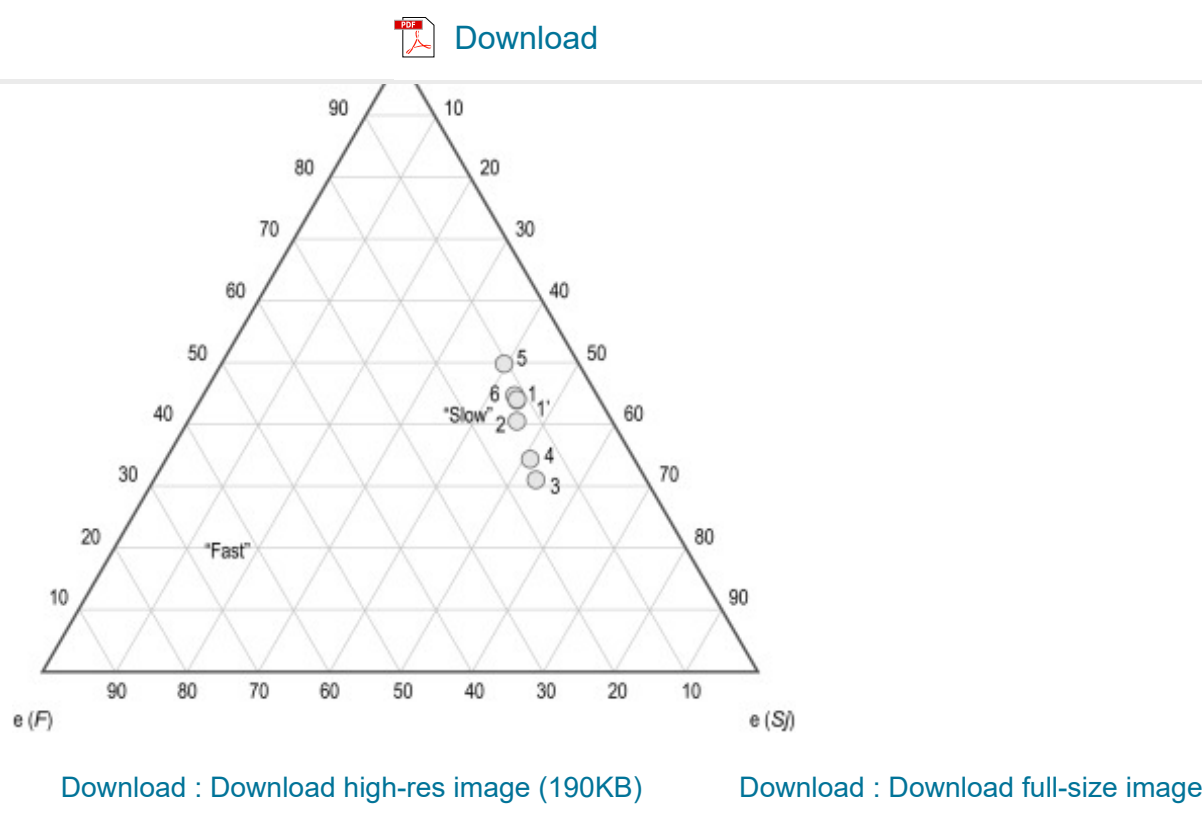

Fig. 5. Ternary diagram of elasticity values of Equus conversidens from the late Pleistocene of Hidalgo and selected populations of extinct and extant Equus. e $(F)$, fecundity; e ( $S j$ ), survivorship of juvenile individuals (o-3 years); e (Sa), survivorship of adults ( $\geq 4$ years). Horse populations: 1, E. conversidens (NISP); 1', E. conversidens (MNI); 2, E. lambei; 3, E. mosbachensis; 4, E. germanicus; 5, E. quagga; 6, E. zebra.

The demographic models of E. conversidens derived from MNI and NISP indices suggest that the survival of prime individuals (>3 years) is more important for population growth, as with E. quagga and E. zebra. The survival of juveniles (o-3 years of age) for E. lambei, E. mosbachensis and E. germanicus is somewhat more important for population growth. Finally, we observed that all the populations considered in this study fall within the "slow" area of the ternary diagram, which also reflects the theory of fast-slow continuum life stories (see review Oli, 2004). Our results are clearly related to the life history of large mammals characterized by late maturity, long lifespan, high survival and fecundity rates as well as higher $\lambda$ in comparison with the "fast model". By the same token, and despite the concerns regarding the adequacy of the r-K selection theory (Stearns, 1992 but see Boyce, 1984), the demographic parameters of all species studied here allow us to classify them as K-strategists in stable ecosystems (Pianka, 1970).

\subsection{Ecological considerations}

The extant plains zebra Equus quagga has a similar body size (ca. 30o kg) and is the closest relative species of $E$. conversidens (Alberdi et al., 1995; Barron-Ortiz et al., 2019), being a suitable model for comparison purposes. Several studies have shown that population dynamics of E. quagga is related to multiple factors, including seasonality, predation, environmental conditions, and/or resource availability (Mohelman, 2002; Georgiadis et al., 2003; Grange et al., 2004, 2015; Funston and Mills, 2006; Owen-Smith, 2008; Rubenstein, 2010; Ransom et al., 2016; Kiffner et al., 2017).

Isotopic ecology and palynological studies indicate that savanna-like habitats with flood plains and channels were present in southeastern Hidalgo during the late Pleistocene (Bravo-Cuevas et al., 2017; Pineda-Maldonado, 2017). This woodlandgrassland ecosystem sustained a high diversity of large mammalian herbivores, providing a suitable environment characterized by diverse food plant resources (Bravo-Cuevas et al., 2017). Considering their flexible feeding strategies, observed through mesowear and stable isotope analyses, individuals of $E$. conversidens were able to exploit the available food resources in different habitats (Bravo-Cuevas et al., 2011, 2017).

We propose that the influence of ambush (American lion) and cursorial social predators (dire wolf) are related to the mortality profile of the population of E. conversidens. Other ungulates that represented potential prey of these large carnivores have been reported at southeastern Hidalgo, including llamas, camels, deer, antelopes, and bison (BravoCuevas et al., 2016). In this regard, populations of E. quagga experience different intensities of predation (Georgiadis et al., 2003; Owen-Smith, 2008; Funston and Mills, 2006), although it is not a limiting factor of population growth if there is an abundance of large preys (Funston and Mills, 2006). 
slightly (Bowyer et al., 2014).

\section{Conclusion}

The current ecological standard tools such as life tables (time-specific model) and Lewis-Leslie matrices, are very efficient to derive paleodemographic parameters from the late Pleistocene cohorts of $E$. conversidens from Hidalgo. We compared this species to a sample of modern equids (E. asinus, E. zebra, E. hemionus, E. caballus) and fossil species (E. mosbachensis, E. germanicus, E. lambei) from different habitats. The mortality pattern of E. conversidens is a primedominated profile sometimes associated to hunting pressure or density-mediated destruction of faunal remains. We propose that the influence of natural predators produced this pattern, considering the association of large-sized predators, such as the dire wolf (Canis dirus) and the American lion (Panthera atrox), at southeastern Hidalgo during the latter half of the Pleistocene. By the same token, it is proposed that population dynamics of E. conversidens from Hidalgo were regulated by predation and resource availability as it occurs in the extant plains zebra, E. quagga.

\section{Authors contribution}

Alexis Pérez-Pérez: Conceptualization, Methodology, analysis, writing. Victor Manuel Bravo-Cuevas: Conceptualization, writing, editing. Philippe Fernandez: Conceptualization, Methodology, writing.

\section{Declaration of competing interest}

The authors declare that they have no known competing financial interests or personal relationships that could have appeared to influence the work reported in this paper.

\section{Acknowledgments}

Thanks to Francisco J. Vega for handling and editing of the manuscript. We acknowledge the comments of the anonymous reviewers that improved the final version of the manuscript. We also appreciate the kind support of Nuria M. Morales-García (Bristol University, UK) for the linguistical review of the text.

\section{Appendix A. Supplementary data}

The following is the Supplementary data to this article:

目 Download: Download Word document (314KB)

Multimedia component 1.

Recommended articles Citing articles (0)

\section{References}

Alberdi et al., 1995 M.T. Alberdi, J.L. Prado, E. Ortiz-Jaureguizar

\section{Patterns of body size changes in fossil and living Equini (Perissodactyla)}

Biol. J. Linn. Soc., 54 (1995), pp. 349-370

Article Download PDF View Record in Scopus Google Scholar

Badgley, 1986 C. Badgley

Counting individuals in mammalian fossil assemblages from fluvial environments

Palaios, 1 (1986), pp. 328-338, 10.2307/3514695

CrossRef View Record in Scopus Google Scholar

Bai et al., 2011 B. Bai, Y. Wang, J. Meng, X. Jin, Q. Li, P. Li 
Palaios, 26 (2011), pp. 187-196, 10.2110/palo.2010.p10-079r

CrossRef View Record in Scopus Google Scholar

Barrón-Ortiz et al., 2019 C.I. Barrón-Ortiz, L.S. Avilla, C.N. Jass, V.M. Bravo-Cuevas, H. Machado, D. Mothé

What is Equus? Reconciling taxonomy and phylogenetic analyses

Frontiers in Ecology and Evolution, 343 (2019), pp. 1-14, 10.3389/fevo.2019.00343

Google Scholar

Bell et al., 2004 Ch J. Bell, E.L. Lundelius Jr., A.D. Barnosky, R.W. Graham, E.H. Lindsay, D.R. Ruez Jr., H.A. Semken Jr., H.A. Webb, R.J. Zakrewski

The blancan, irvingtonian, and rancholabrean mammal ages

M.O. Woodburne (Ed.), Late Cretaceous and Cenozoic Mammals of North America, Columbia University Press, United States (2004), pp. 232-314

CrossRef Google Scholar

Behrensmeyer et al., 2000 A.K. Behrensmeyer, S.M. Kidwell, R.A. Gastaldo

Taphonomy and paleobiology

Paleobiology, 26 (2000), pp. 103-147, 10.1017/So094837300026907

View Record in Scopus Google Scholar

Bernardelli, 1941 H. Bernardelli

Population waves

J. Bihar Res. Soc., 31 (I) (1941), pp. 3-18

Google Scholar

Botkin and Miller, 1974 D.B. Botkin, R.S. Miller

Mortality rates and survival of birds

Am. Nat., 108 (1974), pp. 181-192

http://www.jstor.com/stable/2459849

View Record in Scopus Google Scholar

Bowyer et al., 2014 R.T. Bowyer, V.C. Bleich, B.K.M. Stewart, J.C. Whiting, K.L. Monteith

Density dependence in ungulates: a review of causes, and concepts with some clarifications

Calif. Fish Game, 100 (2014), pp. 550-572

View Record in Scopus Google Scholar

Boyce, 1984 M.S. Boyce

Restitution of $\mathbf{r}$ - and K-selection as a model of density-dependent natural selection

Annu. Rev. Ecol. Evol. Syst., 15 (1984), pp. 427-447, 10.1146/annurev.es.15.110184.002235

CrossRef View Record in Scopus Google Scholar

Brain, 1981 C.K. Brain

The Hunters or the Hunted? an Introduction to African Cave Taphonomy

The University of Chicago Press, Chicago, Illinois (1981), p. 365

View Record in Scopus Google Scholar

Bravo-Cuevas, 2001 V.M. Bravo-Cuevas

Pleistocene faunal assemblage from south-central region of the state of Hidalgo, Central Mexico

J. Vertebr. Paleontol., 21 (2001), p. 35A

Google Scholar

Bravo-Cuevas, 2002 V.M. Bravo-Cuevas

Diferenciación geológica y bioestratigráfica de la Formación Tarango para el estado de Hidalgo, Centro de México, México, Hidalgo, Centro de Investigaciones en Ciencias de la Tierra Universidad Autónoma del Estado de Hidalgo, México, Technical Report (2002), p. 59

View Record in Scopus Google Scholar 
late Pleistocene of Hidalgo and puebla, central Mexico

11th North American Paleontological Conference Program with Abstracts. PaleoBios, 36 (2019), p. 79

Google Scholar

Bravo-Cuevas et al., 2009a V.M. Bravo-Cuevas, M.A. Cabral-Perdomo, E. Ortiz-Caballero, Vargas J. Priego

La Megafauna del Pleistoceno

K.A. González-Rodríguez, C. Cuevas-Cardona, J.M. Castillo-Cerón (Eds.), Los Fósiles del Estado de Hidalgo,

Universidad Autónoma del Estado de Hidalgo, Pachuca, Hidalgo, México (2009), pp. 85-96

View Record in Scopus Google Scholar

Bravo-Cuevas et al., 2009b V.M. Bravo-Cuevas, E. Ortiz-Caballero, M.A. Cabral-Perdomo

Gliptodontes (Xenarthra, Glyptodontidae) del Pleistoceno Tardío (Rancholabreano) de Hidalgo, Centro de México

Bol. Soc. Geol. Mex., 61 (2009), pp. 267-276, 10.18268/BSGM2009v61n2a14

CrossRef View Record in Scopus Google Scholar

Bravo-Cuevas et al., 2011 V.M. Bravo-Cuevas, E. Jiménez-Hidalgo, J. Priego-Vargas

Taxonomía y hábito alimentario de Equus conversidens (Perissodactyla, Equidae) del Pleistoceno Tardío (Rancholabreano) de Hidalgo, centro de México

Rev. Mex. Ciencias Geol., 28 (2011), pp. 65-82

View Record in Scopus Google Scholar

Bravo-Cuevas et al., 2012 V.M. Bravo-Cuevas, E. Jiménez-Hidalgo, G. Cuevas-Ruíz, M.A. Cabral-Perdomo

A small camelid Hemiauchenia from the late Pleistocene of Hidalgo, central Mexico

Acta Palaeontol. Pol., 57 (2012), pp. 497-508, 10.4202/app.2011.0005

CrossRef View Record in Scopus Google Scholar

Bravo-Cuevas et al., 2013 V.M. Bravo-Cuevas, E. Jiménez-Hidalgo, M.A. Cabral-Perdomo, J. Priego-Vargas

Taxonomy and notes on the paleobiology of the late Pleistocene (rancholabrean) antilocaprids (mammalia, artiodactyla, antilocapridae) from the state of Hidalgo, central Mexico

Rev. Mex. Ciencias Geol., 30 (2013), pp. 601-613

View Record in Scopus Google Scholar

Bravo-Cuevas et al., 2015 V.M. Bravo-Cuevas, N.M. Morales-García, M.A. Cabral-Perdomo

Description of mastodons (Mammut americanum) from the late Pleistocene of southeastern Hidalgo, central Mexico

Bol. Soc. Geol. Mex., 67 (2015), pp. 337-347, 10.18268/BSGM2015v67n2a14

CrossRef View Record in Scopus Google Scholar

Bravo-Cuevas et al., 2016 V.M. Bravo-Cuevas, J. Priego-Vargas, M.A. Cabral-Perdomo, M.A. Pineda Maldonado First occurrence of Panthera atrox (Felidae, Pantherinae) in the Mexican state of Hidalgo and a review of the record of felids from the Pleistocene of Mexico

Fossil Record, 19 (2016), pp. 131-141, 10.5194/fr-19-131-2016

CrossRef View Record in Scopus Google Scholar

Bravo-Cuevas et al., 2017 V.M. Bravo-Cuevas, F. Rivals, J. Priego-Vargas

Paleoecology ( $\delta^{13} \mathrm{C}$ and $\delta^{18} \mathrm{O}$ stable isotopes analysis) of a mammalian assemblage from the late Pleistocene of Hidalgo, central Mexico and implications on the better understanding of environmental conditions in temperate North America (18 $-3^{\circ} 6^{\circ} \mathrm{N}$ Lat.)

Palaeogeogr. Palaeoclimatol. Palaeoecol., 485 (2017), pp. 632-643, 10.1016/j.palaeo.2017.07.018

Article Download PDF View Record in Scopus Google Scholar

Bravo-Cuevas et al., 2020 V.M. Bravo-Cuevas, E. Ortiz-Caballero, E. Jiménez-Hidalgo, C.I. Barrón-Ortiz, J.M. Theodor Taxonomía y hábito alimentario de ejemplares de Mammuthus columbi (Proboscidea: elephantidae) del centro y sur de México Bol. Soc. Geol. Mex., 72 (2020), pp. 1-28, 10.18268/BSGM2018v72n1a\# View Record in Scopus Google Scholar 
Download

floridanus (Rodentia) from the early Miocene Thomas Farm site, Florida (USA)

Palaeogeogr. Palaeoclimatol. Palaeoecol., 85 (1991), pp. 1-14, 10.1016/0031-0182(91)90022-J

View Record in Scopus Google Scholar

Burke, 1998 A. Burke, J. Cinq-Mars

Paleoethological reconstruction and taphonomy of Equus lambei from the bluefish Caves, Yukon territory, Canada

Artic, 51 (1998), pp. 105-115, 10.14430/arctic1052

View Record in Scopus Google Scholar

Caswell, 1978 H. Caswell

A general formula for the sensitivity of population growth rate to changes in life history parameters

Theor. Popul. Biol., 14 (1978), pp. 215-230, 10.1016/0040-5809(78)90025-4

Article Download PDF View Record in Scopus Google Scholar

Caswell, 2001 H. Caswell

Matrix Population Models: Construction, Analysis and Interpretation

(second ed.), Sinauer Associates, Sunderland, Massachusetts (2001), p. 722

Google Scholar

Caswell and Weeks, 1986 H. Caswell, D.E. Weeks

Two-sex models: chaos, extinction, and other dynamic consequences of sex

Am. Nat., 128 (1986), pp. 707-735, 10.1086/284598

View Record in Scopus Google Scholar

Caughley, 1966 G. Caughley

Mortality patterns in mammals

Ecology, 47 (1966), pp. 906-918

CrossRef Google Scholar

Caughley, 1977 G. Caughley

Analysis of Vertebrate Populations

John Wiley and Sons, London (1977), p. 234

View Record in Scopus Google Scholar

Discamps and Costamagno, 2015 E. Discamps, S. Costamagno

Improving mortality profile analysis in zooarchaeology: a revised zoning for ternary diagrams

J. Archaeol. Sci., 58 (2015), pp. 62-76, 10.1016/j.jas.2015.03.021

Article Download PDF View Record in Scopus Google Scholar

Dodd and Stanton, 1990 J.R. Dodd, R.J. Stanton

Populations in Paleoecology

J.R. Dodd, R.J. Stanton (Eds.), Paleoecology: Concepts and Applications, John Wiley and Sons, New York (1990),

pp. 277-322

Google Scholar

Driver and Maxwell, 2013 J.C. Driver, D. Maxwell

Bison death assemblages and the interpretation of human hunting behavior

Quat. Int., 297 (2013), pp. 100-109, 10.1016/j.quaint.2012.12.038

Article Download PDF View Record in Scopus Google Scholar

Erickson et al., 2006 G.M. Erickson, P.J. Currie, B.D. Inouye, A.A. Winn

Tyrannosaur life tables: an example of nonavian dinosaur population biology

Science, 313 (2006), pp. 213-217, 10.1126/science.1125721

CrossRef View Record in Scopus Google Scholar 


\section{Download}

population biology

Anat. Rec., 292 (2009), pp. 1514-1521, 10.1002/ar.20992

CrossRef View Record in Scopus Google Scholar

Fernandez, 2009 P. Fernandez

De l'estimation de l'âge individuel dentaire au modèle descriptif des structures d'âge des cohortes fossiles: l'exemple des Equidae et du time-specific model en contextes paléobiologiques pléistocènes

Bull. Soc. Prehist. Fr., 106 (2009), pp. 5-14, 10.3406/bspf.2009.13826

CrossRef View Record in Scopus Google Scholar

Fernandez and Legendre, 2003 P. Fernandez, S. Legendre

Mortality curves for horses from the Middle Palaeolithic site of Bau de l'Aubesier (Vaucluse, France): methodological, palaeo-ethnological, and palaeo-ecological approaches

J. Archaeol. Sci., 30 (2003), pp. 1577-1598, 10.1016/S0305-4403(03)00054-2

Article Download PDF View Record in Scopus Google Scholar

Fernandez and Boulbes, 2010 P. Fernandez, N. Boulbes

Analyse démographique des cohortes du cheval pléistocène moyen de Romain-la-Roche (Doubs, France)

Rev. Paleobiol., 29 (2010), pp. 771-801

View Record in Scopus Google Scholar

Fernandez et al., 2006 P. Fernandez, J.-L. Guadelli, P. Fosse

Applying dynamics and comparing life tables for Pleistocene Equidae in anthropic (Bau de

l'Aubesier, Combe-Grenal) and carnivore (Fouvent) contexts with modern feral horse populations (Akagera, Pryor Mountain)

J. Archaeol. Sci., 33 (2006), pp. 176-184, 10.1016/j.jas.2005.07.005

Article Download PDF View Record in Scopus Google Scholar

Fernandez et al., 2017 P. Fernandez, C. Bonenfant, J.M. Gaillard, S. Legendre, H. Monchot

Life tables and Leslie matrices for mammalian cohorts in different paleobiological contexts during the Pleistocene

J.P. Brugal (Ed.), Taphonomies, Editions des Archives Contemporaines, Paris (2017), pp. 477-497

View Record in Scopus Google Scholar

Fourvel et al., 2014 J.B. Fourvel, P. Fosse, P. Fernandez, P.O. Antoine

La grotte de Fouvent, dit l'Abri Cuvier (Fouvent-le-Bas, Haute-Saône, France): analyse taphonomique d'un repaire d'hyènes du Pléistocène supérieur (OIS 3)

Paléo, 25 (2014), pp. 79-99, 10.400o/paleo.2747

CrossRef Google Scholar

Fourvel et al., 2015 J.B. Fourvel, P. Fosse, P. Fernandez, P.O. Antoine

Large mammals of fouvent saint-andoche (Haute-Saône, France): a glimpse into a late Pleistocene hyena den

Geodiversitas, 37 (2015), pp. 237-266, 10.5252/g2015n2a5

CrossRef View Record in Scopus Google Scholar

Funston and Mills, 2006 P.J. Funston, M.G.L. Mills

The influence of lion predation on the population dynamics of common large ungulates in the Kruger National Park

S. Afr. J. Wildl. Res., 36 (2006), pp. 9-22

View Record in Scopus Google Scholar

Fujiwara and Diaz-Lopez, 2017 M. Fujiwara, J. Diaz-Lopez

Constructing stage-structured matrix population models from life tables: comparison of methods

PeerJ, 5 (2017), Article e3971 
Download

Gallard et al., 2000 J.Iv. Gallard, IV. Festa-Blanchet, N.G. Yoccoz, A. Lolson, C. I olgo

Temporal variation in fitness components and population dynamics of large herbivores

Annu. Rev. Ecol. Evol. Syst., 31 (2000), pp. 367-393, 10.1146/annurev.ecolsys.31.1.367

CrossRef View Record in Scopus Google Scholar

Garrott and Taylor, 1990 R.A. Garrott, L. Taylor

Dynamics of a feral horse population in Montana

J. Wildl. Manag., 54 (1990), pp. 603-612, 10.2307/3809357

CrossRef View Record in Scopus Google Scholar

Georgiadis et al., 2003 N. Georgiadis, M. Hack, K. Turpin

The influence of rainfall on zebra population dynamics: implications for management

J. Appl. Ecol., 40 (2003), pp. 125-136, 10.1046/j.1365-2664.2003.00796.x

View Record in Scopus Google Scholar

Grange et al., 2004 S. Grange, P. Duncan, J.-M. Gaillard, A.R.E. Sinclair, P.J.P. Gogan, C. Packer, H. Hofer, M. East

What limits the Serengeti zebra population?

Oecologia, 140 (2004), pp. 523-532, 10.1007/s00442-004-1567-6

View Record in Scopus Google Scholar

Grange et al., 2015 S. Grange, F. Barnier, P. Duncan, J.-M. Gaillard, M. Valeix, H. Ncube, S. Périquet, H. Fritz

Demography of plains zebras (Equus quagga) under heavy predation

Popul. Ecol., 57 (2015), pp. 201-214, 10.1007/s10144-014-0469-7

CrossRef View Record in Scopus Google Scholar

Grayson, 1979 D.K. Grayson

On the quantification of vertebrate archaeofaunas

M.B. Schiffer (Ed.), Advances in Archaeological Method and Theory, vol. 2, Academic Press, New York (1979), pp.

199-237

Google Scholar

Grayson, 1984 D.K. Grayson

Quantitative Zooarchaeology: Topics in the Analysis of Archaeological Faunas

Academic Press, New York (1984), p. 202

View Record in Scopus Google Scholar

Hood, 2008 G.M. Hood

PopTools version 3.2.5

Available online at:

http://www.cse.csiro.au/poptools (2008)

Google Scholar

Hulbert, 1982 R.C. Hulbert Jr.

Dynamics of the three-toed horse neohipparion from the late miocene of Florida

Paleobiology, 8 (1982), pp. 159-167, 10.1017/So094837300004504

View Record in Scopus Google Scholar

Hulbert, 1984 R.C. Hulbert Jr.

Paleoecology and population dynamics of the early Miocene (Hemingfordian) horse Parahippus leonensis from the Thomas Farm site, Florida

J. Vertebr. Paleontol., 4 (1984), pp. 547-558, 10.1080/02724634.1984.10012030

CrossRef View Record in Scopus Google Scholar

Hunter, 1998 J.P. Hunter

Paleoecology meets ecology on questions of scale

Trends Ecol. Evol., 13 (1998), pp. 478-479

Article Download PDF View Record in Scopus Google Scholar 
Download

Document produced by Working Group 1 of the Joint Committee for Guides in Metrology (JCGM/WG 1) (2008), p. 134

https://www.bipm.org/fr/publications/guides/

Google Scholar

Joubert, 1974 E. Joubert

Composition and limiting factors of a Khoma Hochland population of Hartmann zebra Equus zebra hartmannae

Madoqua, 1 (1974), pp. 49-53

View Record in Scopus Google Scholar

Kahlke and Gaudzinski, 2005 R.D. Kahlke, S. Gaudzinski

The blessing of a great flood: differentiation of mortality patterns in the large mammal record of the Lower Pleistocene fluvial site of Untermassfeld (Germany) and its relevance for the interpretation of faunal assemblages from archaeological sites

J. Archaeol. Sci., 32 (2005), pp. 1202-1222, 10.1016/j.jas.2005.03.004

Article Download PDF View Record in Scopus Google Scholar

Kiffner et al., 2017 C. Kiffner, H. Rheault, E. Miller, T. Scheetz, V. Enriquez, R. Swafford, J. Kioko, H.H.T. Prins

Longterm population dynamics in a multi-species assemblage of large herbivores in East Africa

Ecosphere, 8 (2017), Article e02027, 10.1002/ecs2.2027

CrossRef Google Scholar

Klein and Cruz-Uribe, 1984 R.G. Klein, K. Cruz-Uribe

The Analysis of Animal Bones from Archeological Sites

University of Chicago Press, Chicago, Illinois (1984), p. 273

View Record in Scopus Google Scholar

Koike and Ohtaishi, 1985 H. Koike, N. Ohtaishi

Prehistoric hunting pressure estimated by the age composition of excavated Sika deer (Cervus nippon) using the annual layer of tooth cement

J. Archaeol. Sci., 12 (1985), pp. 443-456

Article Download PDF View Record in Scopus Google Scholar

Koike and Ohtaishi, 1987 H. Koike, N. Ohtaishi

Estimation of prehistoric hunting rates based on the age composition of (Cervus nippon)

J. Archaeol. Sci., 14 (1987), pp. 251-269

Article Download PDF View Record in Scopus Google Scholar

Korth and Evander, 1986 W.W. Korth, R.L. Evander

The use of age-frequency profiles of micromammals in the determination of attritional and catastrophic mortality of fossil assemblages

Palaeogeogr. Palaeoclimatol. Palaeoecol., 52 (1986), pp. 227-236, 10.1016/0031-0182(86)90048-9

Article Download PDF View Record in Scopus Google Scholar

Kurtén, 1953 B. Kurtén

On the variation and population dynamics of fossil and recent mammal populations

Acta Zool. Fennica, 76 (1953), pp. 1-112

View Record in Scopus Google Scholar

Kurtén, 1954a～B. Kurtén

Population dynamics and evolution

Evolution, 8 (1954), pp. 75-81, 10.1111/j.1558-5646.1954.tboo110.x

CrossRef Google Scholar

Kurtén, 1954b B. Kurtén

Population dynamics: a new method in paleontology 
Kurtén, 1983 B. Kurtén

Variation and dynamics of a fossil antelope population

Paleobiology, 9 (1983), pp. 62-69

View Record in Scopus Google Scholar

Lemos-Espinal et al., 2005 J.A. Lemos-Espinal, R.I. Rojas-González, J.J. Zúñiga-Vega

Técnicas para el Estudio de Poblaciones de Fauna Silvestre

CONABIO, Universidad Nacional Autónoma de México (2005), p. 157pp

Google Scholar

Leslie, 1945 P.H. Leslie

On the use of matrices in certain population mathematics

Biometrika, 33 (1945), pp. 183-212, 10.1093/biomet/33.3.183

CrossRef View Record in Scopus Google Scholar

Leslie, 1948 P.H. Leslie

Some further notes on the use of matrices in population mathematics

Biometrika, 35 (1948), pp. 213-245, 10.2307/2332342

CrossRef Google Scholar

Leslie, 1966 P.H. Leslie

The intrinsic rate of increase and the overlap of successive generations in a population of Guillemot (Uria aalge Pont.)

J. Anim. Ecol., 35 (1966), pp. 291-301

https//doi.org/10.2307/2396

CrossRef View Record in Scopus Google Scholar

Levine, 1983 M.A. Levine

Mortality models and the interpretation of horse population structure

G. Bailey (Ed.), Hunter-Gatherer Economy in Prehistory: A European Perspective, Cambridge University Press,

Cambridge (1983), pp. 23-46

View Record in Scopus Google Scholar

Lewis, 1942 E.G. Lewis

On the generation and growth of a population

Sankhya, 6 (1942), pp. 93-96

View Record in Scopus Google Scholar

Lindström and Kokko, 1998 J. Lindström, H. Kokko

Sexual reproduction and population dynamics: the role of polygyny and demographic sex differences

Proc. Roy. Soc. Lond. B, 265 (1998), pp. 438-488, 10.1098/rspb.1998.0320

Google Scholar

Lkhagvasuren et al., 2017 D. Lkhagvasuren, N. Batsaikhan, W.F. Fagan, E.C. Ghandakly, P. Kaczensky, T. Müller, R.

Samiya, R. Schafberg, A. Stubbe, M. Stubbe, H. Ansorge

First assessment of the population structure of the Asiatic wild ass in Mongolia

Eur. J. Wildl. Res., 64 (2017), p. 3, 10.1007/s10344-017-1162-X

Google Scholar

Lyman, 1987 R.L. Lyman

On the analysis of vertebrate mortality profiles: sample Size, mortality type, and hunting pressure

Am. Antiq., 52 (1987), pp. 125-142, 10.2307/281064

CrossRef View Record in Scopus Google Scholar

Lyman, 1994 R.L. Lyman 
Download

View Record in Scopus Google Scholar

Lyman, 2008 R.L. Lyman

Quantitative Paleozoology

Cambridge University Press, Cambridge (2008), p. 348

Google Scholar

MacFadden, 1989 B.J. MacFadden

Dental character variation in paleopopulations and morphospecies of fossil horses and extant analogs

D.R. Prothero, R.M. Schoch (Eds.), The Evolution of Perissodactyls, Oxford University Press, New York (1989), pp.

128-141

Google Scholar

MacFadden, 2008 B.J. MacFadden

Geographic variation in diets of ancient populations of 5-million-year-old (early Pliocene) horses from southern North America

Palaeogeogr. Palaeoclimatol. Palaeoecol., 226 (2008), pp. 83-94, 10.1016/j.palaeo.2008.03.019

Article Download PDF View Record in Scopus Google Scholar

Marín et al., 2017 J. Marín, P. Saladié, A. Rodríguez-Hidalgo, E. Carbonell

Neanderthal hunting strategies inferred from mortality profiles within the Abric Romaní sequence

PloS One, 12 (2017), Article e0186970, 10.1371/journal.pone.0186970

CrossRef Google Scholar

Martín-González et al., 2016 J.A. Martín-González, A. Mateos, G. Rodríguez-Gómez

A parametrical model to describe a stable and stationary age structure for fossil populations

Quat. Int., 413B (2016), pp. 69-77, 10.1016/j.quaint.2016.01.038

Article Download PDF View Record in Scopus Google Scholar

McDonald, 1996 H.G. McDonald

Population structure of the late pliocene (blancan) zebra Equus simplicidens (perissodactyla: equidae) from the hagerman horse quarry, Idaho

K.M. Stewart, K.L. Seymour (Eds.), Palaeoecology and Palaeoenvironments of Late Cenozoic Mammals, University of Toronto, Canada (1996), pp. 134-155

CrossRef Google Scholar

Mihlbachler, 2003 M.C. Mihlbachler

Demography of late Miocene rhinoceroses (Teleoceras proterum and Aphelops malacorhinus)

from Florida: linking mortality and sociality in fossil assemblages

Paleobiology, 29 (2003), pp. 412-428

https://doi:10.1666/0094-8373(2003)0292.0.CO

View Record in Scopus Google Scholar

Mihlbachler, 2007 M.C. Mihlbachler

Sexual dimorphism and mortality bias in a small Miocene North American rhino, Menoceras arikarense: insights into the coevolution of sexual dimorphism and sociality in rhinos

J. Mamm. Evol., 14 (2007), pp. 217-238

https://doi:10.1007/s10914-007-9048-4

CrossRef View Record in Scopus Google Scholar

Mihlbachler, 2012 M.C. Mihlbachler

Palaeodemographics of small-bodied mammals in Pleistocene environments: a case study of muskrats (Ondatra zibethicus: rodentia: Muridae) from north Florida

Biol. J. Linn. Soc., 106 (2012), pp. 41-56

CrossRef View Record in Scopus Google Scholar 
Download

the upper Pleistocene site of geula cave (mount carmel, Israel)

J. Archaeol. Sci., 39 (2012), pp. 3027-3038

Article Download PDF View Record in Scopus Google Scholar

Munson, 2000 P.J. Munson

Age-correlated differential destruction of bones and its effects on archaeological mortality profile of domestic sheep and goats

J. Archaeol. Sci., 27 (2000), pp. 391-407, 10.1006/jasc.1999.0463

Article Download PDF View Record in Scopus Google Scholar

Munson and Marean, 2003 P.J. Munson, C.W. Marean

Adults only? A reconsideration of Middle Paleolithic 'prime-dominated' reindeer hunting at Salzgitter Lebenstedet

J. Hum. Evol., 44 (2003), pp. 263-273, 10.1016/So047-2484(02)00163-X

View Record in Scopus Google Scholar

Munson and Garniewicz, 2003 P.J. Munson, R.C. Garniewicz

Age-mediated survivorship of ungulate mandibles and teeth in canid-ravaged faunal assemblages

J. Archaeol. Sci., 30 (2003), pp. 405-416, 10.1006/jasc.2002.0850

Article Download PDF View Record in Scopus Google Scholar

Nimmo, 1971 B.W. Nimmo

Population dynamics of a Wyoming pronghorn cohort from the Eden-Farson site, $485 W 304$

Plains Anthropol., 16 (1971), pp. 285-288

View Record in Scopus Google Scholar

Oli, 2004 M.K. Oli

The fast-slow continuum and mammalian life-history patterns: an empirical evaluation

Basic Appl. Ecol., 5 (2004), pp. 449-463, 10.1016/j.baae.2004.06.002

Article Download PDF CrossRef View Record in Scopus Google Scholar

Owen-Smith, 2008 N. Owen-Smith

The comparative population dynamics of browsing and grazing ungulates

I.J. Gordon, H.T. Prins (Eds.), The Ecology of Browsing and Grazing, Springer-Verlag, Berlin (2008), pp. 149-178

CrossRef View Record in Scopus Google Scholar

Pearl and Miner, 1935 R. Pearl, J.R. Miner

Experimental studies on the duration of life. XIV. The comparative mortality of certain lower organisms

QRB (Q. Rev. Biol.), 10 (1935), pp. 60-79

View Record in Scopus Google Scholar

Pianka, 1970 E.R. Pianka

On r- and K-Selection

Am. Nat., 104 (1970), pp. 592-597, 10.1086/282697

View Record in Scopus Google Scholar

Pineda-Maldonado, 2017 M.A. Pineda-Maldonado

Interpretación paleoambiental de un ecosistema del Pleistoceno tardío en Epazoyucan, sureste de Hidalgo mediante palinología y un análisis ecomorfológico

MSc. Dissertation. Universidad Autónoma del Estado de Hidalgo, Mexico (2017)

Google Scholar

Prentiss et al., 2014 A.M. Prentiss, H.S. Cail, L.M. Smith

At the malthusian ceiling: subsistence and inequality at bridge river, British columbia

J. Anthropol. Archaeol., 33 (2014), pp. 34-48, 10.1016/j.jaa.2013.11.003

Article Download PDF View Record in Scopus Google Scholar 
J.I. Ransom, P. Kaczensky (Eds.), Wild Equids. Ecology, Management, and Conservation, Johns Hopkins University Press, Baltimore, Maryland (2016), pp. 68-83

View Record in Scopus Google Scholar

Reher, 1970 C.A. Reher

\section{Population dynamics of the Glenrock Bison bison population}

G.C. Frison (Ed.), The Glenrock Buffalo Jump, 48CO34: Late Prehistoric Period Buffalo Procurement and Butchering on the Northwestern Plains, vol. 7, Plains Anthropologist Memoir (1970), pp. 51-55

View Record in Scopus Google Scholar

\section{Reher, 1973 C.A. Reher}

The Wardell Bison bison sample: population dynamics and archaeological Interpretation

G.C. Frison (Ed.), The Wardell Buffalo Trap, 48SH301: Communal Procurement in the Upper Green River Basin, Wyoming, University of Michigan Anthropology Papers No. 48, Ann Arbor (1973), pp. 89-105

View Record in Scopus Google Scholar

Reher, 1974 C.A. Reher

Population study of the Casper site Bison

G.C. Frison (Ed.), The Casper Site: A Hell Gap Bison Kill on the High Plains, Academic Press, New York (1974), pp. $113-124$

Google Scholar

Rodríguez-Gómez et al., 2014 G. Rodríguez-Gómez, A. Mateos, J.A. Martín-González, R. Blasco, J. Rosell, J. Rodríguez Discontinuity of human presence at atapuerca during the early middle Pleistocene: a matter of ecological competition?

PloS One, 9 (2014), Article e101938, 10.1371/journal.pone.0101938

CrossRef View Record in Scopus Google Scholar

Rodríguez-Gómez et al., 2016 G. Rodríguez-Gómez, A. Mateos, J.A. Martín-González, J. Rodríguez

Measuring intraguild competition from faunal assemblages to compare environmental conditions among paleocommunities

Quat. Int., 413B (2016), pp. 55-68, 10.1016/j.quaint.2015.11.087

Article Download PDF View Record in Scopus Google Scholar

RStudio Team, 2015 RStudio Team

RStudio: integrated development for R. RStudio, PBC, boston, Massachusetts

Available online at:

http://www.rstudio.com/ (2015)

Google Scholar

Rubenstein, 2010 D.I. Rubenstein

Chapter 7 - ecology, social behavior, and conservation in zebras

Adv. Stud. Behav., 42 (2010), pp. 231-258, 10.1016/Soo65-3454(10)42007-0

Article Download PDF View Record in Scopus Google Scholar

Rubenstein and Nuñez, 2009 D.I. Rubenstein, C.M. Nuñez

Sociality and reproductive skew in horses and zebras

R. Hager, C.B. Jones (Eds.), Reproductive Skew in Vertebrates-Proximate and Ultimate Causes, Cambridge

University Press, Cambridge (2009), pp. 196-226

CrossRef View Record in Scopus Google Scholar

Ruffner and Carothers, 1982 G.A. Ruffner, S.W. Carothers

Age structure, condition and reproduction of two Equus asinus (equidae) populations from grand Canyon national park, Arizona

SW. Nat., 27 (1982), pp. 403-411, 10.2307/3670715

CrossRef Google Scholar 
Download

kruger national park

S. Afr. J. Wildl. Res., 6 (1976), pp. 99-112

Google Scholar

Spinage, 1972 C.A. Spinage

African ungulate life tables

Ecology, 53 (1972), pp. 645-652, 10.2307/1934778

CrossRef View Record in Scopus Google Scholar

Stearns, 1992 S.C. Stearns

The Evolution of Life Histories

Oxford University Press, Oxford, United Kingdom (1992), p. 249

View Record in Scopus Google Scholar

Steele, 2005 T.E. Steele

Comparing methods for analysing mortality profiles in zooarchaeological and paleontological samples

Int. J. Osteoarchaeol., 15 (2005), pp. 1-17

View Record in Scopus Google Scholar

Steele and Weaver, 2002 T.E. Steele, T.D. Weaver

The modified triangular graph: a refined method for comparing mortality profiles in archaeological samples

J. Archaeol. Sci., 29 (2002), pp. 317-322, 10.1006/jasc.2001.0733

Article Download PDF View Record in Scopus Google Scholar

Steinsalz and Orzack, 2011 D. Steinsalz, S.H. Orzack

Statistical methods for paleodemography on fossil assemblages having small numbers of specimens: an investigation of dinosaur survival rates

Paleobiology, 37 (2011), pp. 113-125

Google Scholar

Stephens and Krebs, 1986 D.W. Stephens, J.R. Krebs

Foraging Theory

Princeton University Press, Princeton (1986), p. 247

View Record in Scopus Google Scholar

Stiner, 1990 M.C. Stiner

The use of mortality patterns in archaeological studies of hominid predatory adaptations

J. Anthropol. Archaeol., 9 (1990), pp. 305-351, 10.1016/0278-4165(90)90010-B

Article Download PDF View Record in Scopus Google Scholar

Stiner, 1991 M.C. Stiner

Human Predator and Prey Mortality

Westview Press, Boulder (1991), p. 276

Google Scholar

Stiner, 1994 M.C. Stiner

Honor Among Thieves: a Zooarchaeological Study of Neandertal Ecology

Princeton University Press, Princeton (1994), p. 447

Google Scholar

Stott, 2018 I. Stott

Popdemo: demographic modelling using projection matrices

Available online at:

https://cran.r-project.org/web/packages/popdemo/vignettes/popdemo.html (2018)

Google Scholar 
Download

the Washakie formation (Late Eocene), Southern Wyoming: an ecological accident in the fossil record

Palaeogeogr. Palaeoclimatol. Palaeoecol., 63 (1988), pp. 91-108

Article Download PDF View Record in Scopus Google Scholar

Van Valen, 1963 L. Van Valen

Selection in natural populations: Merychippus primus, a fossil horse

Nature, 197 (1963), pp. 1181-1183

CrossRef View Record in Scopus Google Scholar

Van Valen, 1964 L. Van Valen

Age in two fossil horse populations

Acta Zool., 45 (1964), pp. 93-110

View Record in Scopus Google Scholar

Van Valen, 1965 L. Van Valen

Selection in natural populations. III. Measurement and estimation

Evolution, 19 (1965), pp. 514-528

View Record in Scopus Google Scholar

Vasileiadou et al., 2007 K. Vasileiadou, J.J. Hooker, M.E. Collinson

Quantification and age structure of semi-hypsodont extinct rodent populations

Journal of Taphonomy, 5 (2007), pp. 15-41

View Record in Scopus Google Scholar

Voorhies, 1969 M.R. Voorhies

Taphonomy and Population Dynamics of an Early Pliocene Vertebrate Fauna, Knox County,

Nebraska

University of Wyoming, Contributions of Geology Special Paper (1969), pp. 1-69

CrossRef View Record in Scopus Google Scholar

View Abstract

(C) 2020 Published by Elsevier Ltd.

Remote access

Shopping cart

Advertise

Contact and support

Terms and conditions

Privacy policy

We use cookies to help provide and enhance our service and tailor content and ads. By continuing you agree to the use of cookies.

Copyright $(\odot) 2020$ Elsevier B.V. or its licensors or contributors. ScienceDirect $\AA^{\circledR}$ is a registered trademark of Elsevier B.V.

ScienceDirect $₫$ is a registered trademark of Elsevier B.V. 